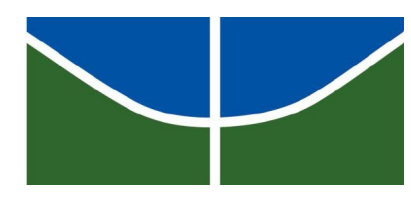

UNIVERSIDADE DE BRASÍLIA

Centro de Excelência em Turismo

Pós-graduação Lato Sensu

Curso de Especialização em Formação de Professores em Turismo

VISITAÇÃO ESCOLAR AO PALÁCIO DO PLANALTO:

CIDADANIA E TURISMO CÍVICO

Cesar Augusto Serena Pinto

Prof ${ }^{\mathrm{a}}$. Dr ${ }^{\mathrm{a}}$. Sandra Lestinge

Prof ${ }^{\circ}$ Msc. Luis Henrique de Souza

Brasília - 2009 


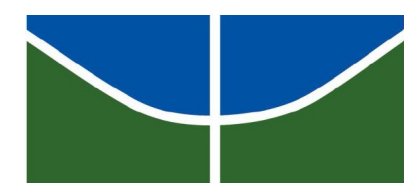

UNIVERSIDADE DE BRASÍLIA

Centro de Excelência em Turismo

Pós-graduação Lato Sensu

Curso de Especialização em Formação de Professores em Turismo

\title{
VISITAÇÃO ESCOLAR AO PALÁCIO DO PLANALTO: CIDADANIA E TURISMO CÍVICO
}

\author{
Cesar Augusto Serena Pinto \\ Prof ${ }^{\mathrm{a}}$. Dr ${ }^{\mathrm{a}}$. Sandra Lestinge
}

Profo. Msc. Luís Henrique de Souza

Monografia apresentada ao Curso de Especialização em Formação de Professores na área de Turismo da Universidade de Brasília-UNB como requisito parcial para obtenção do titulo de especialista em Turismo.

Brasília - 2009 
Pinto, César Augusto Serena

A importância da visitação escolar ao Palácio do Planalto como propiciadora da cidadania e favorecedora do Turismo Cívico/ Pinto, César Augusto Serena - Brasília, 2009. 48 p.

Monografia (especialização) - Universidade de Brasília, Centro de Excelência em Turismo, 2009.

Orientadora:

1. Cidadania. 2. Visitação ao Palácio do Planalto. 3. Turismo Cívico. 


\author{
UNIVERSIDADE DE BRASÍLIA \\ Centro de Excelência em Turismo \\ Pós-graduação Lato Sensu \\ Curso de Especialização em Formação de Professores em Turismo
}

\title{
VISITAÇÃO ESCOLAR AO PALÁCIO DO PLANALTO: \\ CIDADANIA E TURISMO CÍVICO
}

Monografia apresentada ao Centro de Excelência em Turismo - CET, da Universidade de Brasília - UnB, como requisito parcial à obtenção do grau de Especialista em Formação de Professores em Turismo

\section{César Augusto Serena Pinto}

Monografia aprovada em 27 de julho de 2009.

Banca examinadora:

Professora orientadora: PROF ${ }^{a}$. DR ${ }^{a}$. SANDRA LESTINGE

Professora: M.Sc. MARA FLORA LOTTICI KRAHL

Brasília, 2009. 
Dedico este trabalho aos meus familiares, em especial a minha esposa Rosângela e a minha filha Liziane. Aos meus pais, amigos, colegas e especialmente a DEUS. 


\section{AGRADECIMENTOS}

A meus orientadores Luís e Sandra,

que me auxiliaram neste trabalho desde seu início até sua finalização.

À Professora Mara Flora, pelo apoio. 
"A felicidade é algo que a vida nos outorga através de pequenas porções de bem".

Carlos Gonzáles Bernardo Pecoche 


\section{RESUMO}

O turismo pode ser compreendido também como uma atividade que propicia a aprendizagem, e assim serve de instrumento para o cidadão na medida em que proporciona o resgate de conceitos que estão difusos na sociedade, como o de civismo. Nesse sentido, este trabalho teve como foco investigar a visitação ao Palácio do Planalto, realizada por escolas do Distrito Federal como um possível mecanismo para alavancar o Turismo Cívico, e, dessa forma, corresponder à expectativa de injeção de recursos financeiros no local receptor. Percebeu-se que esta atividade constituiu objeto de interesse crescente, tanto por parte do público em geral como das escolas públicas e particulares, às quais a Coordenação de Relações Públicas do Palácio do Planalto (COREP) dá apoio integral ao organizar um programa com iniciativas que favorecem a comunicação sobre fatos atrelados ao exercício da cidadania.

Palavras-chave: Cidadania; Palácio do Planalto; Turismo Cívico. 


\begin{abstract}
The Tourism is understood as an activity that facilitates learning. Specifically, this activity can serve as an instrument for the exercise of citizenship and contribute, through the knowledge which it provides, for the development of concepts and notions, for example, a new concept of citizenship. Thus, this paper focused on the visitation of the Palácio do Planalto by schools in the Distrito Federal as a mechanism that can be transformed into Civic Tourism, if it was extended to schools in other units of the federation of the country, so it correspond to the basic concept of tourism, which is the injection of financial resources at the receiving site. The visit to the Palácio do Planalto has a crescent interest by both the general public as the public and private schools, which the Coordenação de Relações Públicas do Palácio do Planalto (COREP) gives full support. The goal of this paper is to present the program of public visitation at the Palácio do Planalto, as an initiative that promotes the exercise of citizenship and can be extended to schools in other federal units in Brazil, in order to promote Civic Tourism in Brasília.
\end{abstract}

Keywords: citizenship; Palácio do Planalto (Planalto Palace); Civic Tourism. 


\section{SUMÁRIO}

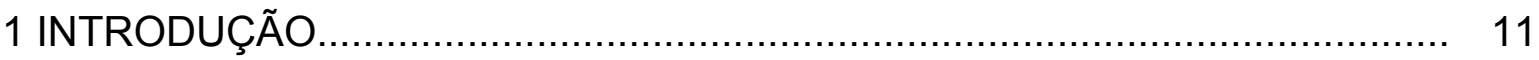

2 TURISMO: PRESSUPOSTOS CONCEITUAIS E TIPIFICAÇÃO.................... 14

3 O TURISMO CÍVICO NO CONTEXTO DO TURISMO CULTURAL

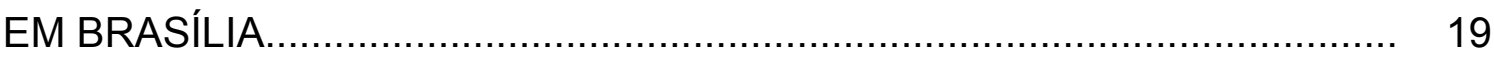

3.10 programa de visitação ao Palácio do Planalto.......................................... 22

3.2 A COREP e os programas do Palácio do Planalto..................................... 23

3.3 A visitação escolar ao Palácio do Planalto e sua perspectiva turística...... 25

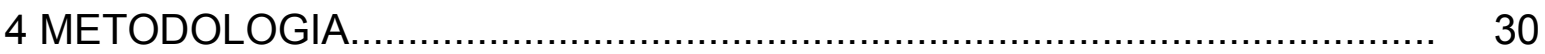

4.1 Documentos pesquisados............................................................. $\quad 30$

4.2 Coleta de Dados....................................................................... 30

4.3 Instrumentos de Pesquisa............................................................... 31

5 RESULTADOS

6 CONSIDERAÇÕES FINAIS................................................................. 39

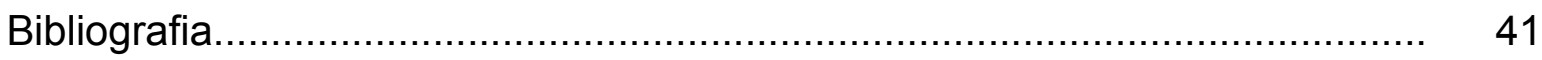

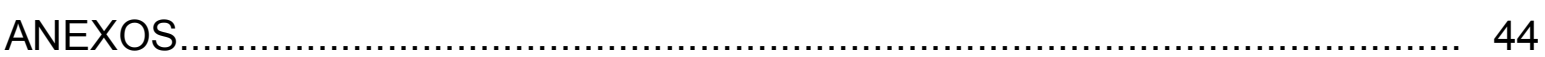




\section{LISTA DE GRÁFICOS}

Gráfico 1 - Visitação pública ao Palácio do Planalto....................................... 23

Gráfico 2 - Visitação de escolas ao Palácio do Planalto................................ 24

Gráfico 3 - Visitações agendadas.......................................................... 24

Gráfico 4 - Formação dos respondentes.................................................. 34

Gráfico 5 - Procedência dos respondentes................................................ 34

Gráfico 6 - Conhecimento do Programa de Visitação do Palácio do Planalto.. 35

Gráfico 7 - Opinião sobre a visitação........................................................... 35

Gráfico 8 - Opinão sobre o conteúdo repassado nas visitas........................... 36

Gráfico 9 - Opinião sobre o atendimento................................................. 36

Gráfico 10 - Opinião sobre o roteiro da visitação........................................... 37

Gráfico 11- Opinião sobre as instalações do Palácio do Planalto.................. 37 


\section{INTRODUÇÃO}

Do ponto de vista das Ciências Sociais, o turismo é um fenômeno social e, por basear-se em movimentos humanos, além de desenvolvimento econômico, implicam processos como aprendizagem, mudança, transformação, valorização patrimonial e outros. Nessa perspectiva, o turismo representa finalidade e meio, seja pelo conhecimento, vivência e experiência.

No caso do Turismo Cívico, segmento abordado neste trabalho, entende-se que possa servir de meio para a formação e para o fortalecimento da noção de civismo, elemento que teve seu valor comprometido no período pós-guerra e na época do regime militar. Aliás, destaque-se que esse comprometimento atingiu, em parte, a própria atividade turística relacionada à cultura da época, pela ideologia com a qual essa atividade foi revestida.

Atualmente, entretanto, com a proposta constitucional da formação de uma consciência cidadã e diante da abertura democrática, o Turismo Cívico apresenta-se como um meio de se retomar conceitos e de se formar outros. Sem a noção de pátria e de sua significação, não se concebe o exercício da cidadania; sem a noção de proximidade entre o poder institucionalizado e o povo, não se concebe a democracia. Desta forma, o Turismo Cívico pode proporcionar esse encontro ao permitir vivências relacionadas com o campo da política, reconstruindo, ao mesmo tempo, o conhecimento, a imagem e a visão do país.

Assim sendo, Brasília, a capital do Brasil, palco das decisões nacionais apresentadas diariamente na mídia a todos os brasileiros, constitui-se em um campo de possibilidades para uma vivência turística importante, principalmente no que se refere à idéia de pertencimento a esse universo, o que geralmente parece distante ao cidadão comum.

O Governo Federal tem estimulado esse tipo de vivência ao promover visitações a seus monumentos e instituições, a exemplo das que ocorrem na Praça dos Três Poderes. A Coordenação de Relações Públicas do Palácio do Planalto (COREP), por exemplo, vem coordenando eventos e desenvolvendo atividades nesse sentido, como visitações tanto de turistas quanto de residentes. No escopo desse trabalho desenvolvido pela COREP esta pesquisa aborda a visitação agendada especialmente organizada para os alunos do $4^{\circ}$ e do $5^{\circ}$ ano do Ensino Fundamental das escolas do Distrito Federal, apresentando essa iniciativa como um 
exemplo a ser estendido para escolas das demais Unidades Federadas, de modo a incentivar o Turismo Cívico no DF.

Nesse contexto, abordam-se os aspectos históricos e conceituais do turismo, enfocando-se os deslocamentos relacionados a assuntos considerados cívicos até a caracterização de Turismo Cívico, numa perspectiva cultural e pedagógico. Para tanto, apresenta-se um sucinto panorama da atividade turística no Distrito Federal, situando o Palácio do Planalto como um dos principais atrativos. Nesse escopo, o foco de análise concentra-se na visitação a esse atrativo como um monumento e como instituição cívica que permite o exercício da democracia ao cidadão.

A partir dessas assertivas deu-se a delimitação do tema deste trabalho, tendo em vista o exercício profissional deste pesquisador no Palácio do Planalto, condição que lhe permitiu observar a crescente rotina de visitação a essa instituição e perceber o grande interesse dos que participam dessa experiência cidadã, principalmente dos alunos.

Este estudo tem como objetivo geral apresentar o Programa de Visitação Pública ao Palácio do Planalto como uma iniciativa que propicia o exercício da cidadania e pode ser ampliado às escolas das demais unidades federadas do Brasil, de modo a favorecer o Turismo Cívico em Brasília.

Têm-se como objetivos específicos, os seguintes:

- destacar os pressupostos do turismo e sua tipificação;

- caracterizar o Turismo Cívico na perspectiva do turismo cultural;

- contextualizar a atividade turística no Distrito Federal sob o recorte do Turismo Cívico;

- analisar o nível de afluência de alunos/visitantes ao Palácio do Planalto, como justificativa de seu favorecimento ao Turismo Cívico em Brasília.

O interesse pelo tema justifica-se, primeiramente, pela citada observação do pesquisador, decorrente de seu exercício profissional no Palácio do Planalto, a partir da qual pode-se perceber que a atividade turística, em termos de possibilidades para o homem, representa bem mais do que deslocamentos, como registrado na Declaração de Montreal, de 1996, no Congresso do Bureau Internacional de Turismo Social (BITS), citado pelo Ministério do Turismo (MTur, 2006, p. 5).

todos os seres humanos têm direito a descansar, a um tempo de ócio, a um limite de horas trabalhadas e a férias pagas (...) o 
objetivo primário de todas as iniciativas de desenvolvimento turístico deve ser a realização plena das potencialidades de cada indivíduo, como pessoa e como cidadão.

O turismo apresenta-se como um importante provedor de concretização de interesses, estimulador de conhecimento e incentivador de cuidados para com a natureza e para com os valores e tradições culturais. Além disso, cabe ao turismo a responsabilidade de articular e promover ações, para que a visitação turística seja um fator de intercâmbio de experiências.

Alguns dados também justificam este estudo: o número de turistas, escolares e convidados que realizaram as visitas guiadas no Palácio do Planalto; a preferência que desse Palácio na hierarquização de prioridades dos turistas: turista de lazer (5 colocação) e do turista de negócios (6a colocação).

Quanto ao foco no Turismo Cívico, considera-se que ele é relevante, principalmente neste momento em que o país busca desenvolver seu processo de democracia e a frequência de turistas aos ambientes da política pode favorecer a compreensão desse processo. Por outro lado, a crescente afluência de visitantes ao Palácio do Planalto é um indicativo do interesse da sociedade nesse sentido. Foi justamente esse o ponto de motivo deste estudo.

O trabalho encontra-se organizado em cinco capítulos, quais sejam: no primeiro, apresenta-se um breve panorama das bases e dos pontos fundamentais do turismo em geral, como forma de contextualizar o Turismo Cívico, a partir de sua tipificação. No segundo, aborda o Turismo Cívico como integrante do Turismo Cultural em Brasília, devido, principalmente, à inter-relação entre o que a capital representa, como centro do poder nacional, e as características monumentais de sua arquitetura. No terceiro capítulo, enfoca-se a visitação de estudantes ao Palácio do Planalto como uma fonte de possibilidades de favorecimento ao Turismo Cívico na cidade, analisando-se os respectivos aspectos. No quarto, descreve-se a metodologia utilizada na pesquisa de campo, apresentando-se, no quinto, seus resultados e discussão.

A pesquisa teve como limitação a pouca bibliografia sobre o Turismo Cívico. 


\section{TURISMO: PRESSUPOSTOS CONCEITUAIS E TIPIFICAÇÃO}

Os deslocamentos humanos, atualmente entendidos como prática turística, ocorrem desde tempos remotos, conforme apontam Shaftesbury e Lickorish (2000, p. 28).

O turismo, apesar de ser um fenômeno já praticado pelas civilizações antigas, só foi reconhecido recentemente como uma atividade econômica de importância global. Como a atividade tornou-se cada fez mais importante, o turismo ganhou a atenção dos governos, das organizações, tanto do setor público como do privado, e dos meios acadêmicos.

O deslocamento é pressuposto para a caracterização do turismo, uma vez que essa prática é intrinsecamente associada a viagens e a visitas a locais distintos do lugar de residência das pessoas. Assim, o turismo em termos históricos teve início quando o homem deixou de ser sedentário e passou a viajar, principalmente motivado pela necessidade de comércio com outros povos. É aceitável, portanto, admitir que o turismo de negócios ${ }^{1}$ antecedeu o turismo para fins de lazer ${ }^{2}$, visto que os deslocamentos realizados para trocas comerciais e para participação em eventos ocorrem desde as antigas civilizações e tornaram-se comuns a partir da Revolução Industrial, quando as viagens tomaram grande impulso, facilitadas principalmente pelo aprimoramento dos meios de transporte e de comunicação.

Para a Organização Mundial de Turismo (OMT), o deslocamento deve ocorrer por um período de 24 horas ou mais e não deve ser confundido com uma atividade rotinizada (movimento de ida para o trabalho e negócios), nem com migração (deslocamento populacional de uma região para outra). O turismo é definido como um "movimento semelhante ao de rotinização, que pode ocorrer em fins de semana, em férias, em eventos, em temporadas ou de modo sazonal" (CASTRO, 2002, p. 111).

Quanto aos deslocamentos que se enquadram no segmento denominado de Turismo Cívico, pode-se afirmar que também datam de tempos longínquos ao se entender que as viagens com finalidades consideradas de caráter cívico inserem-se

\footnotetext{
1 "Turismo de Negócios e Eventos compreende o conjunto de atividades turísticas decorrentes dos encontros de interesse profissional, associativo, institucional, de caráter comercial, promocional, técnico, científico e social" (Mtur, 2006, p. 5).

2 Embora o lazer seja considerado uma das principais motivações para o turismo existem tipos de turismo que extrapolam esse entendimento, por abranger deslocamentos motivados em outras atividades que não as tipicamente de lazer: Ex: Turismo de Negócios e Eventos, Turismo de Saúde e outros.
} 
na abrangência conceitual oficial de Turismo Cultural elaborado conjuntamente pelo Ministério do Turismo, Ministério da Cultura, Instituto do Patrimônio Histórico e Artístico Nacional (IPHAN), entre outros, e apresentado na publicação Segmentação do Turismo - Marcos Conceituais (Mtur, 2006a, p.10).

Turismo Cultural compreende as atividades turísticas relacionadas à vivência do conjunto de elementos significativos do patrimônio histórico e cultural e dos eventos culturais, valorizando e promovendo os bens materiais e imateriais da cultura.

A intrínseca relação turismo e cultura pode ser explicada pelo fato de o produto turístico ser algo vivenciado e essa experiência ocorrer dentro de limites geográficos, caracterizados por condições, costumes e modos de vida específicos. Por centrar-se fundamentalmente na vivência, o turismo cultural está relacionado com a motivação do turista de conhecer patrimônios históricos e culturais, participar de eventos.

Considera-se patrimônio histórico e cultural os bens de natureza material e imaterial que expressam ou revelam a memória e a identidade das populações e comunidades. São bens culturais, de valor histórico, artístico, científico, simbólico, passíveis de atração turística: arquivos, edificações, conjuntos urbanísticos, sítios arqueológicos, ruínas; museus e outros espaços destinados à apresentação ou contemplação de bens materiais e imateriais; manifestações, como música, gastronomia, artes visuais e cênicas, festas e outras. Os eventos culturais englobam as manifestações temporárias, enquadradas ou não na definição de patrimônio. Incluem-se nesta categoria os eventos religiosos, musicais, de dança, de teatro, de cinema, gastronômicos, exposições de arte, de artesanato e outros (Mtur, 2006, p. 14).

Por sua vez, a vivência com o objeto ocorre em dois tipos de relação: a primeira se refere ao aprendizado e ao entendimento do objeto da visitação; a segunda, às experiências participativas, contemplativas e de entretenimento, decorrentes do objeto de visitação (MTur, 2006).

Essas duas formas de relação são também conhecidas, respectivamente, como: tradicional, quando há visitação a locais determinados, em horário previamente definido e rígido e com direito a fotografias; interativa, quando o turista interage com o objeto observado, procurando vivenciá-lo e absorvendo informações de forma natural (MOLETTA, 2001).

Para essa autora, o Turismo Cultural foi expandido devido a fatores sociais associados à vida urbana, como: busca de conhecimento e de formação educacional; retorno às origens familiares e procura por hábitos e costumes dos 
antepassados; intercâmbio cultural e troca de informações e costumes; modismo e ascensão social.

Enquadra-se nessa concepção de Turismo Cultural o segmento denominado Turismo Cívico, conforme oficialmente delimitado:

O Turismo Cívico ocorre em função de deslocamentos motivados pelo conhecimento de monumentos, fatos, observação ou participação em eventos cívicos, que representem a situação presente ou a memória política e histórica de determinados locais (Mtur, 2006, p.10).

Ainda segundo a citada publicação do MTur, entendem-se por monumentos

as obras ou construções que remetam à memória de determinado fato relevante ou personagem. Os fatos são ações, acontecimentos e feitos realizados, ou que estejam ocorrendo na contemporaneidade. Turisticamente, podem atrair pessoas para conhecerem os locais onde se passaram, de forma a compreender o seu contexto e suas particularidades. Neste caso, tais monumentos e fatos diferenciam-se dos demais, por seu caráter cívico, ou seja, relativos à pátria (MTur 2006, p. 16).

Por eventos cívicos, o documento do MTur explicita

todo acontecimento programado de caráter cívico, englobando-se aqui os eventos para troca de bandeiras, posses de presidentes, governadores, prefeitos; comemorações de feriados nacionais relacionados a fatos da pátria, entre outros (MTur 2006, p. 16).

O Turismo Cívico abrange, ainda, "elementos do passado e do presente relacionados à pátria: fatos, acontecimentos, situações, monumentos referentes a feitos políticos e históricos [....] As temáticas envolvidas podem relacionar-se à política municipal, estadual, nacional ou internacional” (MTur, 2006, p. 16).

Quanto aos aspectos históricos do Turismo Cívico no Brasil, pode-se dizer que também remetem aos primórdios da vida político administrativa do país, desde que existiram deslocamentos para, por exemplo, ouvir pronunciamentos dos nossos monarcas ou simplesmente para ver a família real. Para fins de interesses do Estado, têm-se referência que foi utilizado pela primeira vez na chamada Era Vargas, na qual três circunstâncias demonstram como o turismo foi sentido e incorporado por aquele governo à estruturação e fortalecimento do Estado Novo, conforme descreve Santos Filho (2007). 
- a primeira tendência usou o turismo como forma de controle social e transformou os eventos cívicos e militares em atividades organizadas pelo Departamento de Imprensa e Propaganda (DIP), por meio da Divisão de Turismo. Essa controlava o conteúdo do material de divulgação difundido interna e internacionalmente sobre o Brasil e recebia técnicos e profissionais do mundo da comunicação internacional. O turismo teve um papel extremamente revelador para os países que estavam sob regime militar "e foi utilizado pelo Estado como forma de controle ideológico, adquirindo um poder policialesco das estruturas burocráticas preparadas para manter a ordem e firmar diante da opinião pública a imagem do Presidente" ( $p .105)$;

- a segunda considerou o turismo uma fonte de renda, com o Rio de Janeiro já figurando em cartazes do mundo todo como um pólo turístico a ser visitado, um paraíso tropical:

o governo conscientizou-se de que as atividades turísticas eram amplas e podiam agregar valor de forma rápida e constante, facilitando um amplo processo de empregabilidade para a economia e se constituía, ainda, em um instrumento fundamental para cristalizar a imagem do Estado Novo. Percebe-se, assim, que o Estado começava a sentir que havia necessidade da elaboração de um programa nacional de turismo" (p. 114 ).

- a terceira circunstância entendeu o turismo como um importante instrumento para o desenvolvimento interno econômico, social e político e também em relação a outros governos. O Estado Getulista compreendeu a importância do turismo, do ponto de vista econômico e político, e começou a administrar a atividade como se ela fosse um instrumento do Estado. Dessa forma, exigiu um Plano Nacional de Turismo, idéia que tomou corpo nos governos seguintes. Por exemplo, no governo de Juscelino Kubitschek, a lógica do turismo girou em torno da inauguração da Capital Federal, sendo criada criando a Companhia Nacional de Turismo (Combratur), um dia antes da fundação de Brasília. No curto período do governo de Jânio da Silva Quadros, o turismo foi esquecido. Na época de João Goulart, o turismo ficou sob a gestão do Ministério da Indústria e Comércio, na Divisão de Turismo e Certames (p. 114). 
Em 1964, o governo militar criou a Empresa Brasileira de Turismo (Embratur), sendo o turismo também utilizado como instrumento de apoio ao regime. As campanhas publicitárias da época mostravam ao mundo e aos brasileiros um país sem problemas políticos onde reinavam a alegria, o futebol, as praias, o carnaval, imagens que ficaram arraigadas no imaginário mundial.

Pode-se afirmar, assim, que a noção de civismo presente na memória dos brasileiros, de modo geral, contém respingos negativos, vindos, internamente, do amargor ideológico, e externamente, do preconceito que se desenvolveu a partir de uma visão superficial e até fútil do país e de seu povo.

Embora os conteúdos e práticas educacionais que incentivam o civismo já fizessem parte do processo de formação escolar no país, passando a ser obrigatório em disciplinas como "Educação Moral e Cívica" (até 1993), houve estigmatização da palavra "cívico" e de tudo com o que ela se relaciona, como se sua noção remetesse as premissas do regime militar.

Atualmente, ante o processo de democracia introduzido pela Constituição Federal de 1988, é necessário que conceitos como o de civismo sejam retomados e inseridos no cotidiano da sociedade, a fim de se construir uma nova visão sobre o que ele significa para a vida pessoal e conjunta dos cidadãos. E se no passado ele foi introduzido obrigatoriamente como disciplina escolar, na atualidade, formas distintas, como o turismo cívico, podem servir de meio para isso.

Nessa perspectiva, Brasília, capital do país, que figura entre os mais importantes centros do turismo cultural do mundo, devido a sua concepção arquitetônica e urbanística, destaca-se também no contexto do turismo cívico, interno e externo.

Pode-se afirmar, então, que o Turismo Cívico no Brasil apresenta-se de maneira mais característica e organizada na capital federal, onde consta como um dos segmentos mais importantes com roteiros e agências de receptivo especializadas para tal fim. 


\section{O TURISMO CÍVICO NO CONTEXTO DO TURISMO CULTURAL EM BRASÍLIA}

Brasília é a única cidade construída no século XX classificada como Patrimônio Cultural da Humanidade pela Organização das Nações Unidas para a Educação, a Ciência e a Cultura (UNESCO).

Em relação à arquitetura, a Capital conta com belos prédios, construções magníficas, com arte presente em todos os lugares. Dentre os atrativos mais visitados estão o Congresso Nacional, a Praça dos Três Poderes, a Catedral, o Museu do Catetinho, a Torre de TV, o Memorial JK e o Santuário Dom Bosco (SETUR/DF, 2008). Também estão o Palácio da Alvorada, residência oficial do Presidente da República, e o Palácio do Planalto, abertos à visitação de acordo com agendas específicas.

Esses bens, entre centenas de outros, integram a Lista do Patrimônio Mundial, Cultural e Natural da UNESCO e são considerados sítios e monumentos de valor excepcional e de interesse universal, cujo desaparecimento se constituiria em enorme perda para toda a humanidade.

São obras integradas ao dia-a-dia da comunidade, criadas por artistas de renome para as instituições, com diferentes materiais, dimensões e técnicas. Por isso, segundo Rollemberg (2009, p. 2).

Conhecer Brasília é uma janela para a sensibilidade e criatividade na interpretação do patrimônio. É conhecer o pensamento do artista pela contemplação e exercício do olhar", podendo atribuir novos significados às suas obras e os atrativos integrantes tanto do círculo turístico usualmente comercializado como em espaços praticamente desconhecidos aos visitantes da cidade.

A cidade conta ainda com várias áreas verdes, como o Parque da Cidade Sarah Kubitscheck, o Parque Nacional de Brasília, mais conhecido como Água Mineral, e o Jardim Botânico. Brasília ainda é conhecida pelo sincretismo religioso, com destaque para o Templo da Boa Vontade (LBV), ou nos seus arredores, como o Vale do Amanhecer, a Cidade Eclética e a Cidade da Paz.

Para Rollemberg (2009, p. 3), os roteiros turísticos de Brasília podem ser reorganizados ou feitos individualmente, conforme o perfil, motivação, tempo e disposição a para pagar algumas visitações. A versatilidade na distribuição das obras de arte e a respectiva interação arquitetônica fazem com que o visitante conheça aspectos intrínsecos de Brasília. Os percursos turísticos incluem tanto 
cartões postais consagrados, como a Catedral e a Igrejinha de Fátima, por exemplo, como espaços do cotidiano, como o Eixo Monumental, traduzindo "o compromisso com o ideário da modernidade, aliando funcionalidade e qualidade de vida à beleza estética e à arte".

Como se observa, Brasília reúne várias expressões culturais, constituindo um polo de turismo cultural em suas ramificações de interesse patrimonial, religioso e místico, entre outras. Sua monumentalidade e o fato de ser a capital do país, centro do poder político e das respectivas decisões, representam atributos que dão à cidade uma inegável vocação para o desenvolvimento do turismo cívico.

No processo de desenvolvimento de um país, o turismo cívico tem potencial para contribuir para a consolidação da democracia, envolvendo o cidadão, o Estado e o setor privado.

Ele se apresenta como ferramenta de inclusão social capaz de promover a conscientização cidadã, política, econômica e cultural dos visitantes que o praticam, promovendo, desta forma, o patriotismo (ROLLEMBERG, 2009).

Em Brasília, o turismo cívico proporciona a todos os turistas, a possibilidade de visitar a capital de todos os brasileiros, ou seja, a própria visitação à cidade já tende a criar um sentimento de pertencimento e a resgatar valores cívicos e patrióticos. De acordo com a BrasíliaTur (2009, p. 4).

O turismo cívico é uma das particularidades da Capital Federal. A Praça dos Três Poderes reúne as sedes das instituições mais importantes do país e é lá que estão o Palácio do Planalto, o Supremo Tribunal Federal e o Congresso Nacional. Nos fins de semana, o cenário do poder --que em geral só se vê no noticiário da tevê e dos jornais abre suas portas para os turistas, recebidas e orientadas por guias e cicerones. É um interessante passeio, no qual crianças e adultos têm a oportunidade de conhecer obras de arte, documentos e peças relevantes da História do Brasil, desde o império até os dias atuais.

Atualmente, é possível fazer uma visita ao Palácio do Planalto, ao Congresso Nacional, ao Supremo Tribunal Federal e até ao Palácio da Alvorada, em dias predeterminados. A visita guiada no Congresso foi instituída em 1996, mas só em 1998 teve um impulso maior, à medida que aumentou a demanda de interessados em conhecer o centro do Poder Legislativo (CÂMARA, 2006).

No período do recesso parlamentar, centenas de visitantes conhecem os bastidores das decisões nacionais no roteiro do turismo cívico de Brasília. No recesso do Congresso, de 22 de dezembro a 2 de fevereiro, turistas e os próprios 
moradores têm a oportunidade de conhecer de perto o ambiente onde ocorrem as grandes decisões nacionais. O Palácio do Congresso Nacional é aberto à visitação durante todo o ano, sendo um dos grandes atrativos do turismo cívico de Brasília. Seus salões Verde, Negro e Azul e o plenário podem ser vistos pelos turistas. Fora do período de recesso, se o turista estiver no Palácio do Congresso, ainda tem a oportunidade de assistir a uma sessão dos parlamentares, podendo inclusive encontrar e conversar com alguns deles.

Os visitantes contam com a assistência de guias qualificados que esclarecem sobre o funcionamento do Poder Legislativo e a história da construção do prédio tombado como patrimônio arquitetônico. Também são mostradas as obras de arte que ornamentam o interior das instituições, a exemplo das esculturas de Alfredo Ceschiatti e dos painéis de Athos Bulcão, Di Cavalcanti e Marianne Peretti. O programa de visitação ainda oferece noções básicas sobre o processo legislativo, elaboração das leis e o trabalho dos parlamentares. São distribuídos folders com as atividades da semana e com informações sobre a Casa em quatro idiomas, português, inglês, francês e alemão (CÂMARA, 2006).

Em agosto de 2000, o Superior Tribunal de Justiça (STJ) noticiou que esse órgão faria parte do roteiro do Turismo Cívico na capital da República.

A partir do final de setembro, as instalações do conjunto arquitetônico que abriga o Superior Tribunal de Justiça, projetadas pelo arquiteto Oscar Niemeyer, poderão ser visitadas por estudantes e turistas de todo o país, inclusive durante os finais de semana. [...] Além das instalações, os visitantes também terão a oportunidade de conhecer o Museu do STJ e a Biblioteca Min. Oscar Saraiva. O ministro Paulo Costa Leite pretende fornecer a turistas e estudantes material sobre a função constitucional e o funcionamento da Corte responsável pelo controle da legislação federal no país (STJ, 2000, p. 2).

Em 2007, o número de visitantes ao Congresso Nacional foi de 151.468, originários de vários estados brasileiros e de outros países. Desse total, 6.388 eram estrangeiros. Nesse total, incluíam-se pessoas que freqüentaram as Casas no expediente normal, com a finalidade de acompanhar as sessões ou votação de projetos.

No primeiro domingo de cada mês é realizada a cerimônia da troca da bandeira que fica permanentemente hasteada no mastro de cem metros de altura, ao lado do Panteão da Pátria, um museu destinado a homenagear os heróis brasileiros. A festa, uma das mais concorridas da Esplanada dos Ministérios, conta com a participação das Forças Armadas e, em geral, há apresentação da esquadrilha 
da fumaça, de canhões que remontam à Guerra do Paraguai e, ainda, retrata de bandas militares (BRASILIATUR, 2009, p. 10).

O objetivo do STJ corresponde à própria idéia que serve de base ao turismo cívico, ou seja, a importância de estudantes e turistas terem contato não só com a arquitetura de Brasília, mas conhecerem o papel desempenhado pelas instituições na democracia do país, conforme explicou Rollemberg (STJ, 2000).

Em termos de manifestações políticos que ocorrem na Praça dos Três Poderes, Brasília recebe, todas as semanas, caravanas de cidadãos que vêm protestar ou reivindicar seus direitos em frente ao prédio do Congresso Nacional. "Essa categoria de visitantes está se afirmando como 'turismo de protesto', já que a participação popular, a cada dia, se incorpora mais ao cenário da capital brasileira" (ROLLEMBERG, 2009, p. 2).

Diante desse quadro, fica demonstrada a vocação de Brasília para o turismo cultural, com destaque para o Turismo Cívico, confirmando, neste caso, a estreita relação entre Turismo, Cultura e civismo.

A importância do Turismo Cívico no escopo da atividade turística de Brasília pode ser destacada nas palavras de Pinheiro (2008, p. 168), segundo o qual, a estimativa é de que, "no Distrito Federal, o Turismo Cívico atende inicialmente 20 mil visitantes/ano, entre turistas, alunos de escolas públicas e privadas e público em geral".

\subsection{O Programa de Visitação ao Palácio do Planalto}

A finalidade deste capítulo é discutir a possibilidade de se considerar a visitação escolar ao Palácio do Planalto como um fator que pode favorecer o Turismo Cívico em Brasília, tendo em vista o crescente interesse demonstrado pelas escolas e alunos em geral, conforme demonstra o respectivo registro da COREP, ao longo dos últimos cinco anos.

Nesta discussão, leva-se em conta que o turismo, do ponto de vista econômico, é caracterizado por Lickorish e Jenkins (2000) como a atividade que implica a injeção receitas financeiras na área receptora (como citado) e que um produto turístico, conforme Lottici Krahl (2002), é algo imaterial e intangível, representado pela experiência vivencial. 


\subsection{A COREP e os Programas do Palácio do Planalto}

Entre as principais atividades realizadas pela COREP está o programa de visitação pública ao Palácio do Planalto, que ocorre aos domingos. No ano de 2005, o atendimento ao público era feito de $9 \mathrm{~h} 30$ às $13 \mathrm{~h}$. A partir de 2006, o horário foi estendido, passando a ser de $9 \mathrm{~h} 30$ às $14 \mathrm{~h} 30$. Com essa medida, registrou-se um aumento do número de visitantes, conforme demonstra o gráfico 1 .

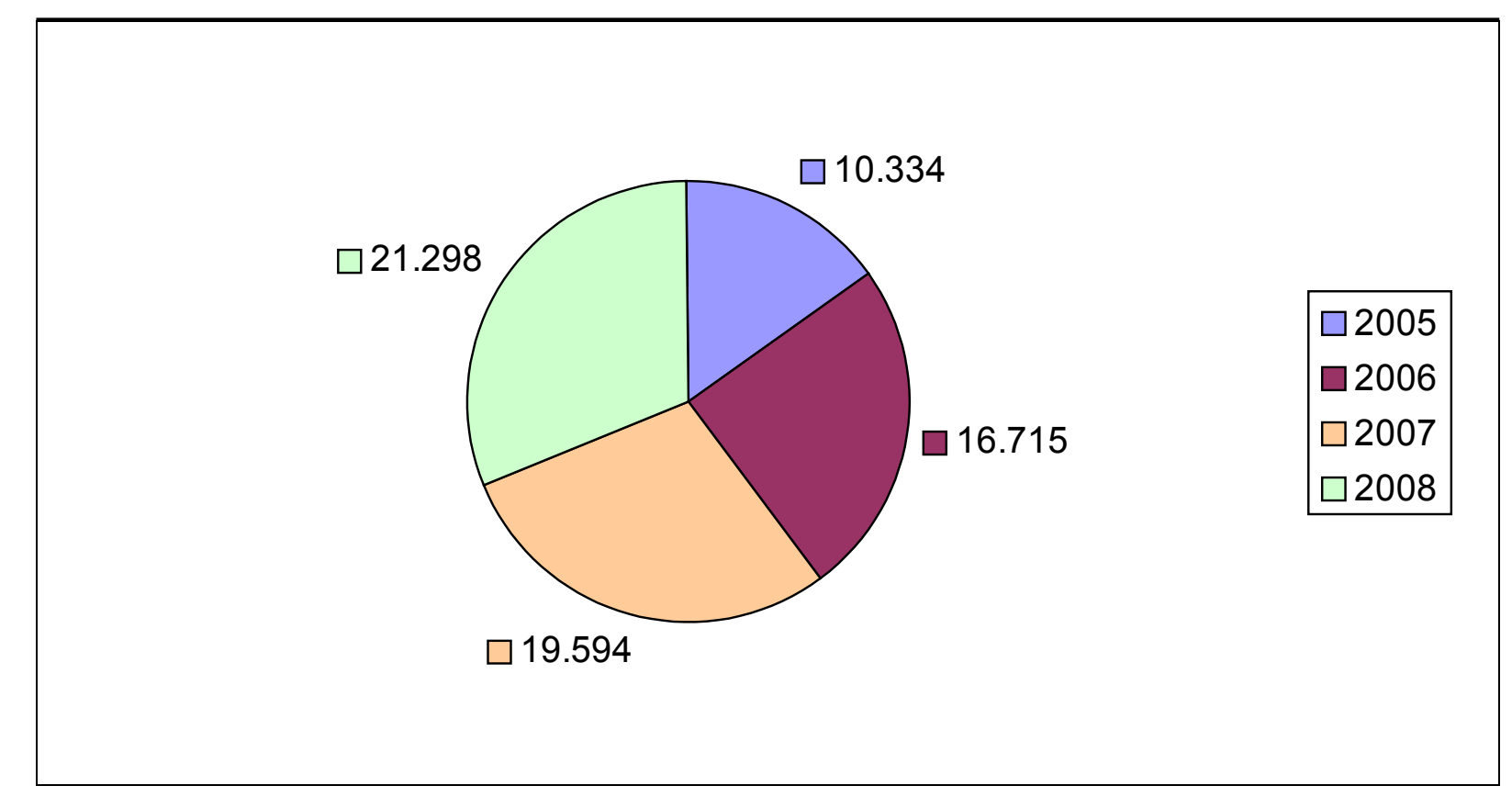

Gráfico 1: Visitação pública ao Palácio do Planalto

O programa de visitação atende também a escolas públicas e particulares do DF e do entorno. É uma atividade na qual os alunos têm a oportunidade de conhecer, por meio de uma aula de civismo, a estrutura organizacional da Presidência da República, bem como a história da criação dos monumentos do complexo criado pelo arquiteto Oscar Niemeyer, juntamente com o urbanista Lúcio Costa.

Em 2005, a Presidência da República recebeu 5.162 alunos; em 2006, foi ampliado o leque de atendimento, incluindo mais um dia da semana para receber escolas; em 2008, o número de alunos visitantes foi de 7.496 (gráfico 2). Esse aumento, bastante significativo, demonstra a eficácia do programa. 


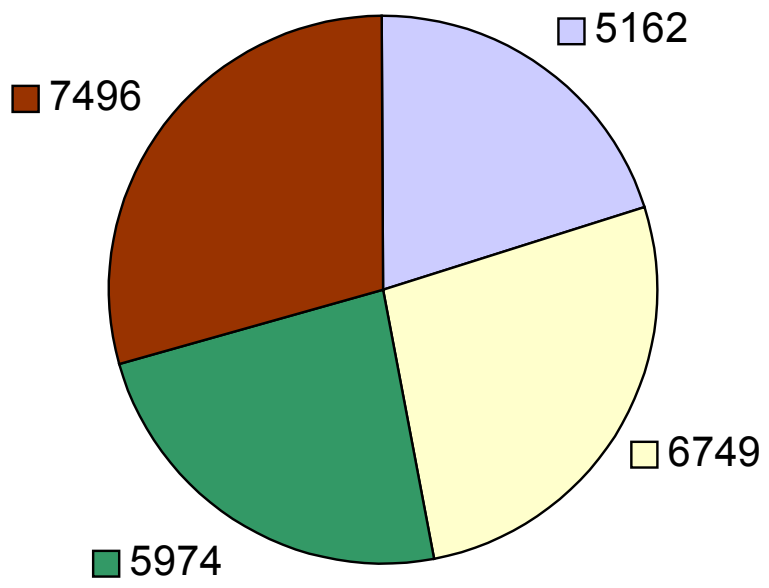

Gráfico 2: Visitação de escolas públicas e particulares ao Palácio do Planalto

Outro tipo de visitação, a agendada, inclui solicitação de autoridades brasileiras e estrangeiras, de estudantes, em sua grande maioria de nível superior e com interesses nas áreas jurídicas e de arquitetura. A decisão de ampliar também esse atendimento possibilitou um aumento da demanda. O gráfico 3 demonstra os números desse tipo de visitação no período de 2005 a 2008.

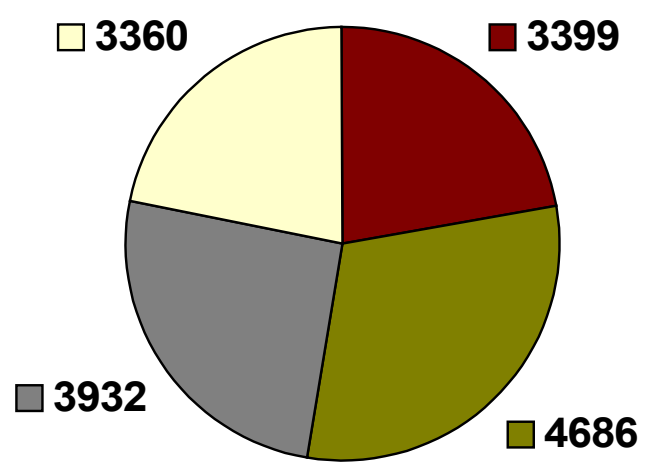


Além do Programa de Visitação, o Palácio do Planalto dispõe de um programa de exposições (ANEXO C), também coordenado pela COREP. As exposições são realizadas nas dependências do Palácio e de seus anexos.

Para a preservação das obras, foi criada a curadoria do Palácio do Planalto em 5 de abril de 2004, formada por representantes do Gabinete Pessoal do Presidente da República, da Casa Civil, do Gabinete de Segurança Institucional e da Secretaria de Comunicação e Gestão Estratégica. Essa Curadoria tem a função de apresentar soluções para a dinamização e a otimização do patrimônio, aconselhar, sugerir e adotar ações de preservação e de restauração, além de ações que objetivam dar a devida grandeza às solenidades, à vida e à ambiência do Palácio do Planalto.

Em outro programa, "Quartas Palacianas", são apresentados filmes nacionais no auditório do anexo I, local que será objeto de ampliações e mudanças. Pretendese também uma parceria com outros órgãos governamentais, para que esse programa seja um canal de divulgação da cultura brasileira.

Para cumprimento de todos esses Programas e com o aumento do horário de atendimento e do número de dias de visitação das escolas, foi necessária a ampliação do quadro de pessoal da COREP, objetivando manter a qualidade desse atendimento. Também houve necessidade de uma melhor qualificação dos servidores envolvidos nas atividades, com a oferta de cursos na área de eventos, cerimonial, excelência no atendimento ao público e curso de línguas para a melhor qualificação da equipe. Em parceria com o Departamento de Segurança, foram ministradas palestras sobre atendimento ao público e etiqueta.

As relações públicas internas também foram atendidas, sendo proporcionados ao servidor momentos de lazer e a oportunidade de se reciclar por meio de palestras promovidas pela COREP. Dessa forma, todos estão aptos a desempenhar a tarefa que lhes compete nos projetos realizados no Palácio do Planalto.

\subsection{A Visitação Escolar ao Palácio do Planalto e sua Perspectiva Turística}

As viagens caracterizadas como Turismo Cívico podem ser chamadas de "viagens-aulas", haja vista os temas relacionados com a vida política do país serem abordados transversalmente. Dessa forma, a atividade turística é utilizada para fins educacionais, prática orientada pelos Parâmetros Curriculares Nacionais (PCNs) (MEC, 1996). A participação dos estudantes no turismo é uma atividade duplamente 
educativa, uma vez que eles viajam em busca de conhecimento e deixam nos destinos visitados, além da renda gerada pela atividade turística, a valorização do seu patrimônio e da sua comunidade.

A Lei de Diretrizes e Bases da Educação (LDB), de 1996, e seus marcos regulatórios dispõem sobre atividades extra-classe, consideradas complementares ao processo de formação educacional do aluno. Essa Lei permite e estimula a flexibilidade das grades curriculares e os respectivos conteúdos programáticos, de forma a adequá-los à realidade local.

Do ponto de vista educacional, essa prática turística caracteriza-se como turismo pedagógico ou turismo educativo, isto é, uma forma de buscar, na diversidade do patrimônio cultural e na biodiversidade, elementos de estudo que enriqueçam o conteúdo pedagógico. O caráter multidisciplinar dessa forma de turismo permite ao jovem aprender por meio da observação e da vivência de diversos fatores (geográficos, históricos, sociais, políticos) que interagem e remetem à realidade. Assim, possibilita aos alunos o desenvolvimento de uma visão crítica e consciente, conforme explica Rodrigo Melo Franco de Andrade (apud DENAMÔNICA, 2002, p. 1): "Em verdade, só há um meio eficaz de assegurar a defesa do patrimônio de arte e de história do país: é a educação popular".

Na perspectiva sociológica, segundo Dumazedier (apud SOUSA, 1994), o turismo é uma atividade que se caracteriza por três funções principais: descansar, divertir e desenvolver. Segundo ele, é lazer quando o indivíduo se entrega de livre vontade a atividades de diversos interesses, que tragam satisfação, sem obrigação alguma. Em acordo com a proposta, o turismo apresenta-se, de modo geral, como uma das práticas mais genuínas de lazer ${ }^{3}$, pois permite total descolamento das atividades cotidianas, proporcionando ambiente adequado para relaxamento e descanso da rotina. Por isso, ele também é diversão, porque libera o indivíduo da monotonia da vida cotidiana. $\mathrm{O}$ turismo é ainda desenvolvimento, porque possibilita a participação do indivíduo na cultura, de forma contemplativa, desinteressada e vivencial, proporcionando conhecimento.

3 Embora o lazer seja considerado uma das principais motivações para o turismo existem tipos de turismo que extrapolam esse entendimento, por abranger deslocamentos motivados em outras atividades que não as tipicamente de lazer: Ex: Turismo de Negócios e Eventos, Turismo de Saúde e outros. 
Essa perspectiva do desenvolvimento corresponde à argumentação do pedagogo francês Freinet (apud RAYKIL; RAYKIL, 2005) que, já em 1925, acreditando que o interesse do estudante não estava na escola, mas sim fora dela, idealizou a aula-passeio para trazer motivação, ação e vida para ao ensino.
A aula-passeio consistia em atividades extraclasse, organizadas coletivamente pelos alunos, onde o essencial era valorizar as necessidades vitais do ser humano - criar, se expressar, se comunicar, viver em grupo, ter sucesso, agir-descobrir, se organizar - tornando-os cidadãos autônomos e cooperativos (RAYKIL; RAYKIL, 2005, p. 2).

Segundo esses autores, do ponto de vista histórico, as chamadas viagens de estudo ocorrem desde o século XVIII, inicialmente realizadas por jovens aristocratas ingleses que visitavam as principais cidades européias; eram então chamadas de grand tour. Hoje, denominada Turismo Pedagógico ou Turismo Educativo, essa atividade vem sendo considerada um importante elemento facilitador do ensino-aprendizagem.

O Turismo Pedagógico representa uma oportunidade de explorar a relação do homem com o espaço em várias perspectivas do conhecimento de forma interativa e multidisciplinar. Essa atividade está em crescimento, uma vez que muitas instituições de ensino estão adotando-a, com a finalidade de integrar conteúdos curriculares em projetos multidisciplinares. Diante desse aspecto interdisciplinar e rico de transmissão do conhecimento socialmente adquirido, o qual se adapta a qualquer nível de escolaridade, as viagens de estudo (ou turismo pedagógico) vêm demonstrando sua eficácia no sentido de permitir uma aprendizagem prática, daquilo que foi teoricamente em sala de aula. Por isso, esse tipo de turismo vem sendo considerado uma prática inovadora, de uso freqüente nas instituições de ensino, inclusive "tornando-se uma oportunidade de negócio que tem estimulado a proliferação de empresas prestadoras de serviços específicos dessa vertente do segmento turístico" (RAYKIL; RAYKIL, 2005, p. 2).

Uma das preocupações da educação é tornar o cidadão crítico e participante da sociedade, já que a palavra cidadania é trabalhada como democracia, como direito de escolha, respeitando seus deveres e direitos. De acordo com Pecotche (1998), a mente da criança é como uma terra virgem e fértil. Por isso, com o 
conhecimento prático, ela tem a possibilidade de formar uma opinião crítica sobre aquilo que vivenciou.

Nesse sentido, ressalta-se também o despertar e o fortalecimento da idéia de civismo e de pertencimento que esse tipo de vivência pode proporcionar, visto ser essa uma preocupação deste pesquisador, diante da realidade da globalização cada vez mais contundente. Essa argumentação pode ser apoiada na seguinte afirmativa de Shaftesbury e Lickorish (2000, p, 29). "[...] o Turismo Cívico tem potencial para contribuir na promoção da justiça social, envolvendo o cidadão em uma inclusão social capaz de promover a conscientização do cidadão".

No que se refere ao Palácio do Planalto, a visitação por alunos de escolas públicas e particulares do DF constitui um excelente estímulo tanto para esses como para os professores, porque estabelece uma relação fundamental entre o presente, o passado e as mudanças que ocorreram entre um e outro.

A exploração do Palácio do Planalto pode envolver também a colaboração de profissionais como arquitetos, planejadores, arqueológicos, antropólogos, historiadores, entre outros, que podem contribuir para a discussão de temas complexos da atualidade, como questões políticas, econômicas, sociais (HORTA, 1999, p. 20).

A visitação de crianças ao Palácio do Planalto representa um amplo campo de investigação, que desperta seu interesse, enquanto possibilita a exploração interdisciplinar envolvendo os alunos em trabalhos fora da sala de aula. Proporciona uma melhor compreensão dos assuntos vistos nas disciplinas de história e geografia, ministrados no ano escolar em que as visitações ocorrem.

Nesse contexto, Raykil e Raykil (2005, p. 4), citando Aziz Ab'Saber, afirmaram que o papel do professor é incentivar os alunos à construção do conhecimento sobre o país e, principalmente, sobre a região onde vivem, "desde os limites territoriais até as características geográficas, econômicas e políticas, essas informações servirão para ele se localizar como cidadão e sempre servirão de base para qualquer estudo de espaços maiores, as chamadas macro-regiões". Por outro lado, o professor que rejeita experiências além da sala de aula acaba perpetuando as práticas do ensino tradicional.

Fanucchi, também citada por Raykil e Raykil (2005, p. 4), defende que "sair da sala de aula e promover atividade fora dos muros da escola é, no mínimo tão importante quanto planejar com cuidado trabalhos no laboratório". 
Viajar, conhecer pessoas e lugares constitui um dos mecanismos que permite ao aluno vivenciar o proposto nos PCN's, ou seja, o exercício de uma cidadania ativa, a qual só ocorre com a vivência relacionada com o objeto de estudo. Para Luck (1994, p. 32), deve-se "estabelecer um sentido significativo às experiências pedagógicas, porque enquanto o conhecimento for explicado de forma fragmentada, como parte da realidade, permanecerá sempre inacabado".

Para Raykil e Raykil (2005), a aquisição de interesse pelos patrimônios natural e cultural do país abre, para os alunos, um mundo de descobertas e de novas experiências que, consequentemente, desperta sua curiosidade para novos conceitos, aumenta sua capacidade intelectual e desenvolve sua sensibilidade e sua criatividade. Aprender pela vivência com o acervo histórico e cultural faz com que o conhecimento seja adquirido ao mesmo tempo que o prazer e de forma dinâmica.

Nesse sentido, no contexto deste trabalho, voltando aos conceitos citados por Lickorish e Jenkins (2000) e Lottici Krahl (2002), respectivamente, a visitação ao Palácio do Planalto por escolas de outras unidades da federação pode constituir-se em atividade turística propriamente dita, pois vai gerar receitas financeiras para a cidade, segundo a definição. Por sua vez, essa visitação vai representar um produto turístico, porque constitui uma experiência vivencial, algo intangível. 


\section{METODOLOGIA}

Trata-se de uma pesquisa descritiva, uma vez que se teve como objetivo apresentar o Programa de Visitação Pública do Palácio do Planalto e a visitação realizada por escolas públicas e privadas do DF como atividade que pode ser estendida a outras escolas do país e favorecer o Turismo Cívico em Brasília. Conforme Richardson et al. (1999), estudos são descritivos quando buscam descrever e caracterizar determinado fenômeno.

A pesquisa foi feita numa abordagem qualitativa e quantitativa, haja vista ter sido utilizado um instrumento que visou mensurar (quantitativo) o nível de atendimento a alunos pelo Programa de Visitação Pública do Palácio do Planalto e o interesse desses (qualitativo).

Quanto aos meios, é uma pesquisa documental, pois os dados foram obtidos por meio de consulta a documentos arquivados no interior da instituição.

É também uma pesquisa de campo, pois foram coletados dados no local onde os sujeitos respondentes se encontram. "Pesquisa de campo é investigação empírica realizada no local onde ocorre ou ocorreu um fenômeno ou que dispõe de elementos para explicá-lo" (VERGARA, 2003, p. 47).

A finalidade dessa pesquisa de campo foi obter uma visão mais atual sobre a visitação ao Palácio do Planalto, tendo em vista a crescente afluência de turistas ano a ano.

\subsection{Documentos Pesquisados}

Serviram de base para esta pesquisa o Relatório de Gestão da Coordenação de Relações Públicas do Palácio do Planalto (COREP), referente ao período de 2005 a 2008.

\subsection{Coleta de Dados}

A pesquisa de campo foi realizada pelo pesquisador entre 4 de janeiro e $1 .^{\circ}$ de março de 2009. Buscou-se averiguar como estudantes, professores e visitantes aproveitam as visitas dirigidas ao Palácio do Planalto, considerando que, segundo Freire (2006, p.47). "[...] ensinar não é transferir conhecimento, mas criar as possibilidades para a sua própria produção ou a sua construção".

Os dados documentais também foram coletados pelo pesquisador, no período compreendido entre maio de junho de 2009, por meio de anotações. 
Também foi feita uma observação artificial nesse período, visando a obter impressões que auxiliassem o alcance do objetivo deste trabalho, no sentido de estender, a outras unidades federativas do país, a visitação de escolas ao Palácio do Planalto e favorecer o Turismo Cívico em Brasília.

Para Gil (2007), a observação é artificial quando o observador passa a integrar o grupo para realizar uma investigação.

Para a realização da pesquisa de campo e da observação artifical, foi solicitada autorização à COREP, da qual se obteve a anuência.

\subsection{Instrumentos de Pesquisa}

Para a investigação de campo, foi utilizado um questionário padrão da COREP (ANEXO B), do qual constam perguntas fechadas e semiabertas, versando sobre aspectos da visitação ao Palácio do Planalto.

$\mathrm{Na}$ observação artificial, foram feitas fotografias de alunos de duas das escolas que visitaram o Palácio no período de janeiro a março de 2009 e anotações sobre o trajeto percorrido pelos alunos nas visitas. 


\section{RESULTADOS}

Os resultados obtidos na pesquisa são apresentados segundo o tipo de instrumento utilizado, ou seja: observação artificial, dados coletados em campo e consulta documental.

Quanto à observação artificial, as informações obtidas se referem ao padrão de visitas estabelecido pela COREP para as escolas: as visitas se dão às terçasfeiras pela manhã, quintas-feiras pela manhã e tarde e, sexta-feira à tarde.

Os grupos de estudantes e professores foram apanhados em suas escolas por um ônibus da Presidência da República e são recebidos em uma área próxima a um dos restaurantes localizados no anexo 4.

A visitação teve início com a oferta de um lanche, quando se explica aos alunos como eles devem proceder durante a visita, pois ela ocorre em locais onde autoridades e funcionários desempenham suas atividades profissionais. Muitas vezes, esse espaço é dividido por chefes de estado de outros países.

Nesse momento, nos dias da pesquisa de campo, deu-se conhecimento aos estudantes e professores que o pesquisador os acompanharia na visitação daquele grupo e que, além de perguntas a serem feitas, seriam tiradas fotos do grupo (anexas) durante o trajeto. Houve anuência de todos.

Para não haver dispersão durante as visitas, indicaram-se banheiros aos alunos e aos professores, antes de iniciarem a visita propriamente dita. Assim, fica mais fácil os professores controlarem os alunos.

Em continuidade, os alunos foram conduzidos ao Palácio do Planalto, dando início ao objetivo da visita. No primeiro momento, no térreo, apresentam-se os uniformes históricos utilizados pelos militares que guarnecem o Palácio. Também são mostradas esculturas e a sala de imprensa.

Em seguida, os grupos foram conduzidos ao elevador de acesso ao segundo andar, quando se observou a emoção de alguns alunos (maioria nas escolas públicas), por ser a primeira vez em que andavam de elevador. Nesse andar se faz a maior parte da visitação; as turmas são conduzidas ao salão oeste, onde se realiza uma foto oficial da visita pelo fotógrafo oficial do Presidente, o que deixa as crianças bastante estimuladas.

Depois, seguiu-se para a parte frontal do Palácio, onde a guarda da rampa presidencial fez uma demonstração de movimento de armas. Explica-se que o 
parlatório é utilizado para a passagem da faixa presidencial e discursos do Senhor Presidente.

$\mathrm{Na}$ visita ao salão leste, as crianças foram informadas de que ali são realizadas solenidades com a presença do Senhor Presidente da República. Nesse momento, perguntou-se aos grupos, crianças e professores, quais eram os símbolos nacionais (bandeira nacional, armas nacionais, selo nacional e o Hino Nacional), e quase ninguém soube responder por completo, apesar de esse assunto ser tema de estudo em sala de aula, de acordo com seu nível escolar.

$\mathrm{Na}$ visita ao salão oval, as crianças se sentaram e foi feita uma explanação sobre os tipos de reuniões, os participantes e os assuntos ali tratados.

Quando conduzidos ao terceiro andar pela rampa interna, solicitou-se uma maior disciplina por parte dos alunos, pois eles passariam em frente à sala do Senhor Presidente, e era um horário em que ele estaria trabalhando. Nesse andar, foram apresentados aos alunos quadros, documentos e fotos pessoais do Senhor Presidente da República. Visitam também a galeria de fotos dos Ex-Presidentes do Brasil.

A visita ao Palácio do Planalto foi encerrada aí, embora a despedida das escolas tenha sido feita na entrada do estacionamento interno, com as turmas sendo conduzidas a suas escolas.

Ao conversar com algumas professoras dias após as visitas, elas afirmaram que a visitação ao Palácio do Planalto favorece muito a aprendizagem dos alunos, porque em muitas ocasiões eles se lembram das informações obtidas durante as visitas. Outro fato relevante a destacar nas conversas foi de que essa visita é tratada nas escolas como prêmio, e somente os melhores alunos e as melhores turmas fazem jus a ele.

Quanto à pesquisa com dados secundários nas visitas guiadas, das 309 pessoas que visitaram o palácio do Planalto entre janeiro e março de 2009, 206 responderam ao questionário.

O nível de escolaridade dos respondentes do questionário foi assim distribuído (gráfico 4): 


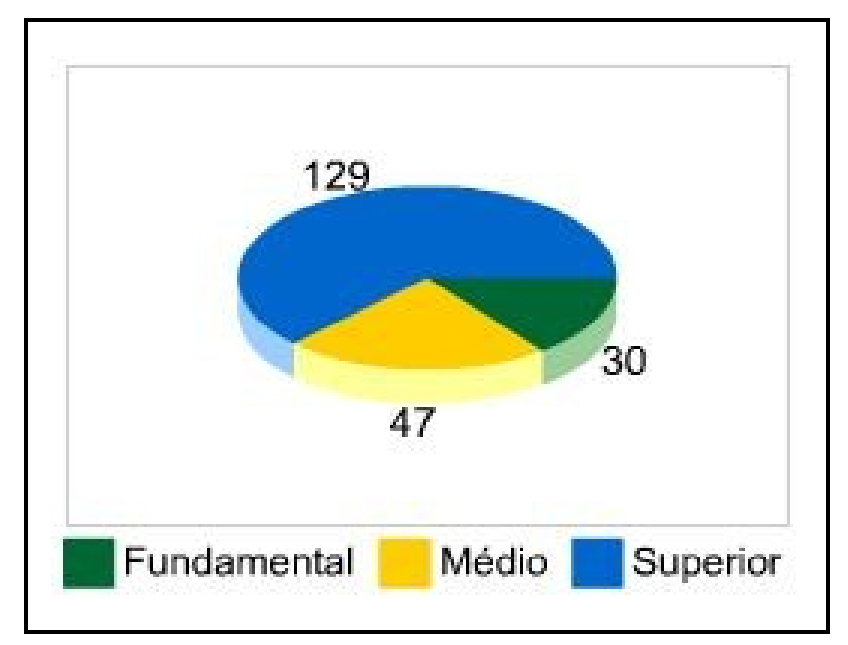

Gráfico 4: Formação dos respondentes

Valores percentuais: Ensino Fundamental - 30 (14.6\%); Ensino Médio - 47 (22.8\%); Nível Superior $129(62.6 \%)$

Sobre a procedência dos visitantes, as respostas foram (gráfico 5):

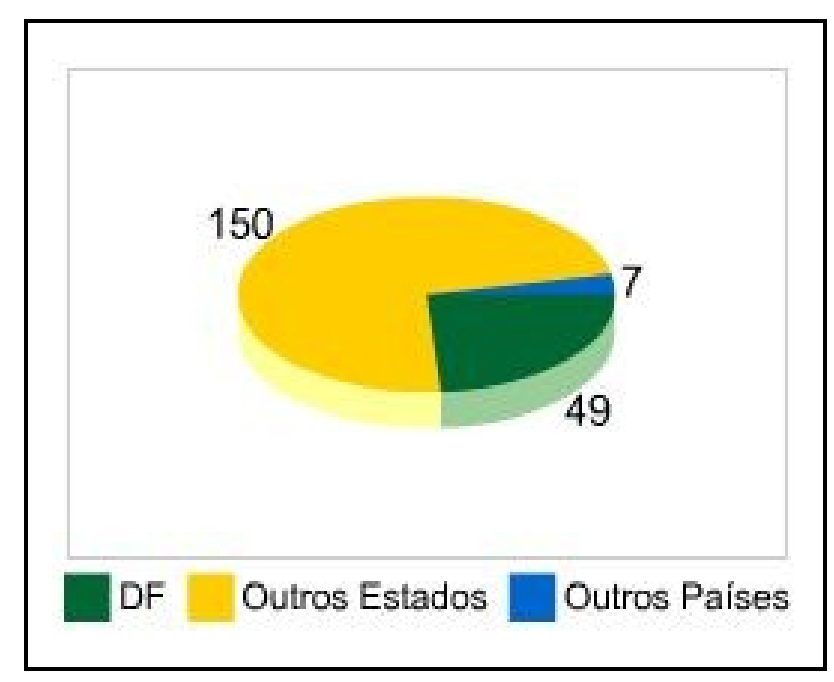

Gráfico 5: Procedência dos respondentes

Valores percentuais: DF - 49 (23.8\%); Outros estados da federação - 150 (72.8\%); Outros países - 7 $(3.4 \%)$

As questões sobre a visitação ao Palácio do Planalto envolveram: forma de conhecimento do Programa de Visitação, a visita, o roteiro interno, conteúdo, coridalidade no atendimento e qualidade das instalações.

Ao serem perguntados sobre como tomaram conhecimento do Programa de Visitação ao Palácio do Planalto, os respondentes informaram (gráfico 6): 


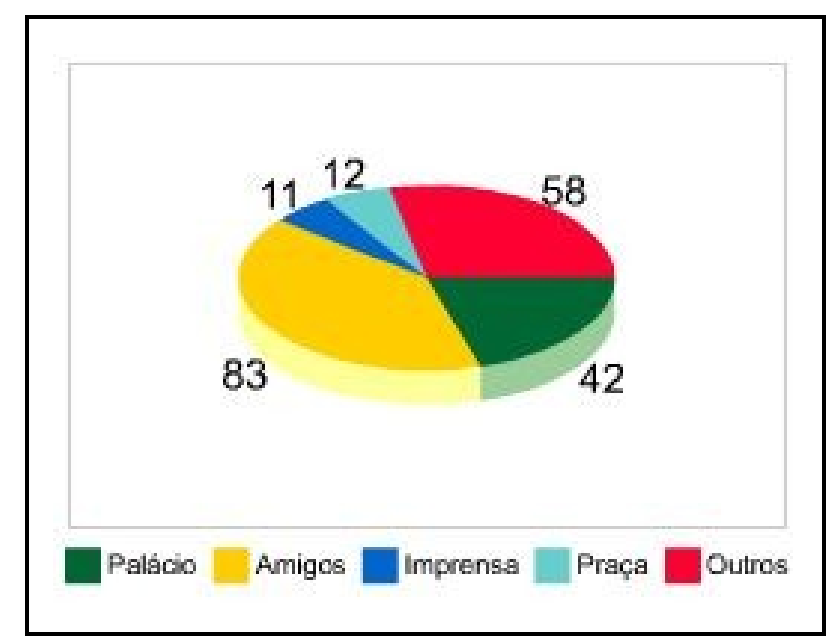

Gráfico 6: Conhecimento do Programa de Visitação do Palácio do Planalto

Valores percentuais: Palácio do Planalto: 42 (20.4\%); amigos: 83 (40.3\%); imprensa: 11 (5.3\%); Praça dos Três Poderes: 12 (5.8\%); outros: 58 (28.2\%).

Observa-se que o Programa de Visitação pode ser mais divulgado por mais canais. Considerando a possibilidade de estendê-lo a escolas de outras unidades da federação, o sistema de informação deve ser ampliado, de modo a que ele possa favorecer o desenvolvimento do Turismo Cívico em Brasília (DF).

Em relação ao percentual de pessoas que gostaram da visitação, o resultado foi (gráfico 7):

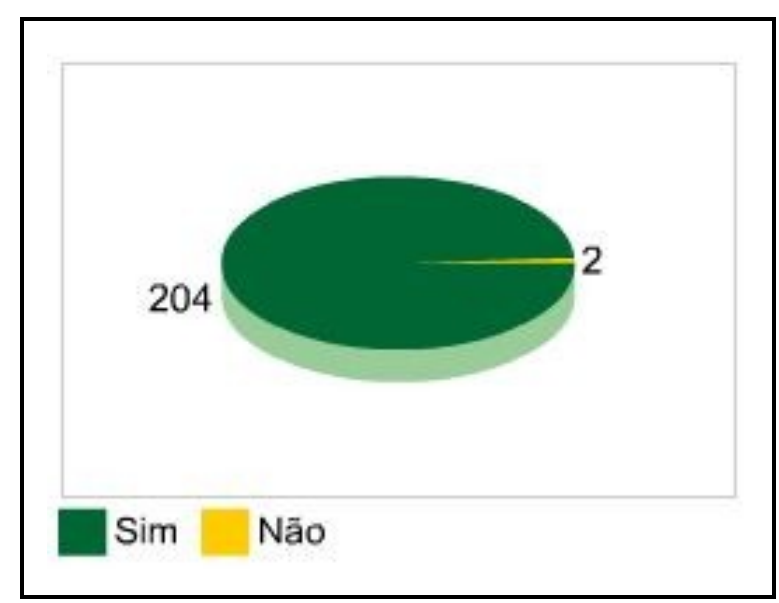

Gráfico 7: Opinião sobre a visita

Valores percentuais: Sim - 204 (99.0\%); Não - 2 (1.0\%)

Esse alto percentual indica que o Programa de Visitação vem sendo bem aceito pelos visitantes em geral, o que é justificado tanto pelo lado do turismo cultural como pelo do Cívico. 
Sobre o conteúdo das informações repassadas durante a visitação, as opiniões foram (gráfico 8):

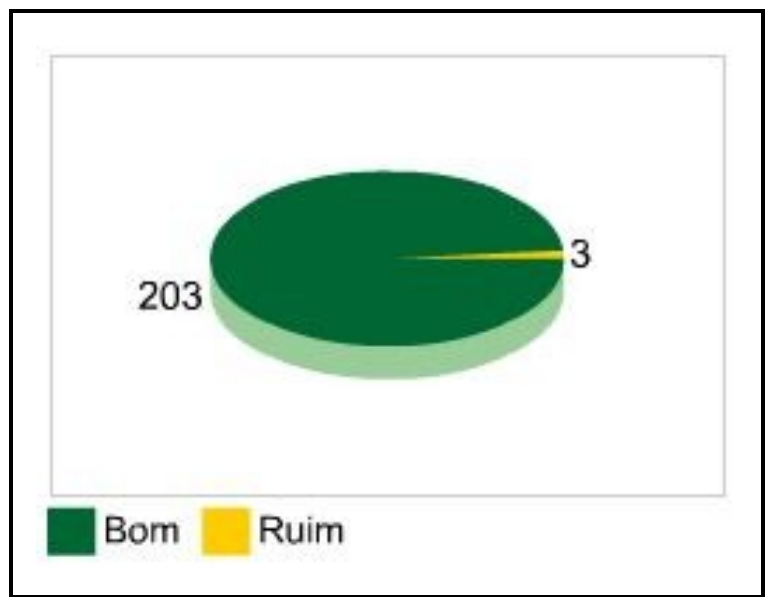

Gráfico 8: Opinião sobre o conteúdo repassado nas visitas

Valores percentuais: Bom - 203 (98.5\%); Ruim - 3 (1.5\%)

Nesse resultado, apenas $0,5 \%$ dos que gostaram da visitação (gráfico 4) não gostou do conteúdo repassado.

Quanto à cordialidade no atendimento durante as visitas, as respostas indicaram o seguinte (gráfico 9):

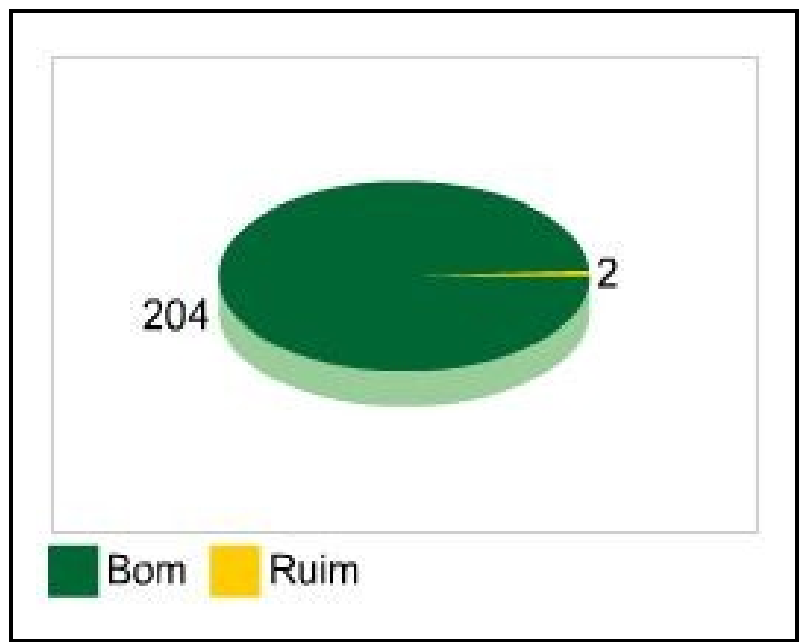

Gráfico 9: Opinião dos visitantes sobre a cordialidade no atendimento

Valores em percentuais: Bom - 204 (99\%); Ruim - 2 (1\%)

No que se refere ao roteiro da visita, foi quase unânime a opinião de que é bom (gráfico 10): 


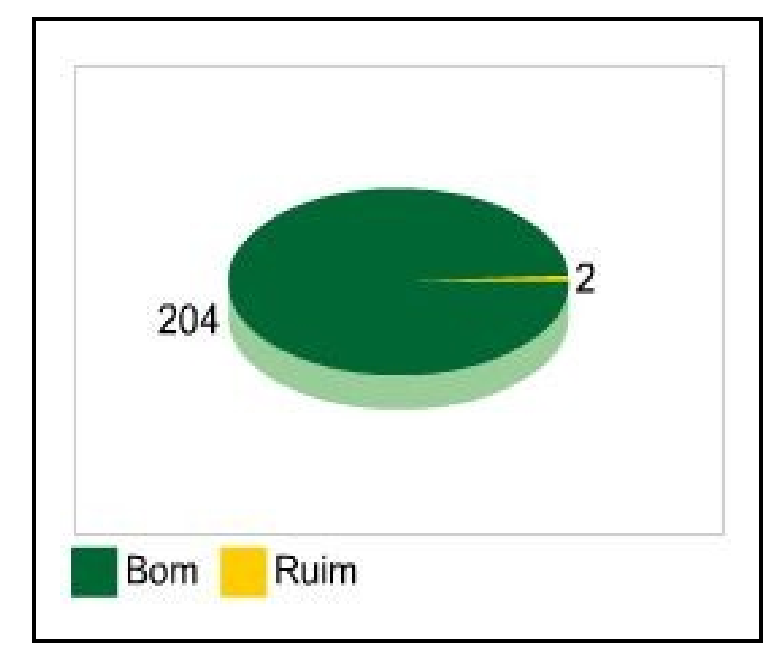

Gráfico 10: Opinião sobre o roteiro da visitação

Valores percentuais: Bom - 204 (99\%); Ruim - 2 (1\%).

Verifica-se que há uma correspondência entre os resultados dos gráficos 7,8 , 9 e 10: os que não gostaram da visita, também não devem ter gostado do conteúdo repassado, do atendimento nem do roteiro da visitação, respectivamente. Possivelmente, esses três últimos tenham contribuído para o resultado do gráfico 4 ou vice-versa, pois afinal, como definiu Lottici Khral (2002), a atividade turística é basicamente vivencial.

Em relação às instalações do Palácio do Planalto (limpeza e conservação), as informações dos respondentes indicaram o seguinte (gráfico 11):

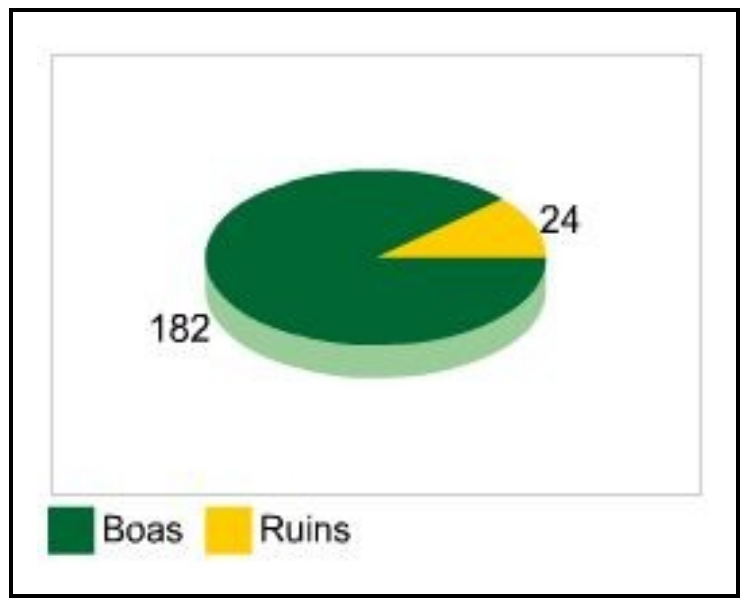

Gráfico 11: Sobre as instalações do Palácio do Planalto

Valores percentuais: Boas - $182(88.3 \%) ;$ Ruins - 24 (11.7\%) 
Esse resultado surpreendeu, mas é justificado, tanto que, pouco tempo depois da pesquisa, o Palácio entrou em reforma, o que vai contribuir para incrementar o turismo e as visitações.

Quanto à pesquisa documental, os dados coletados no Relatório de Gestão da COREP, referentes ao período de 2005 à 2008, demonstraram o aumento gradativo de visitantes ao Palácio do Planalto, inclusive das escolas.

Também se verificou que, em dias que algum chefe de Estado é recebido no Palácio do Planalto, duas escolas são convidadas para assistir o encontro e fazer parte da cerimônia de recepção. Nessas ocasiões, as crianças externalizam sua alegria, pelo fato de estarem próximas de autoridades somente vistas pela mídia.

Há uma política que facilita o agendamento, o transporte e a alimentação dos estudantes para favorecer o acesso ao Palácio do Planalto, principalmente para as escolas públicas. Não havendo demanda por parte das escolas, a COREP convida, por iniciativa própria, instituições escolares, para usufruírem o conteúdo programático das visitações guiadas.

Fica claro que o Palácio do Planalto é uma instituição de interesse geral, prestando-se bastante ao turismo cultural e, através dele, ao cívico. 


\section{CONSIDERAÇÕES FINAIS}

O Palácio do Planalto é um dos monumentos de Brasília e, dessa forma, representa um destino turístico importante, seja na perspectiva de sua arquitetura, seja do ponto de vista cultural, por encontrar-se integrado à vida da cidade, ou do cívico, por constituir o centro do Poder Executivo do país.

Essas características são motivos bastante fortes para atrair o interesse de visitantes, tanto locais como de outras unidades da federação e de outros países, destacando-se ainda, potencialmente, sua vocação para destino específico do Turismo Cívico, como vêm demonstrando os resultados obtidos pelo Programa de Visitação do COREP para as escolas do DF, com o crescente afluxo de alunos.

Considerando a abertura do país para o processo democrático, entende-se que as condições oferecidas pelo Palácio do Planalto para a visitação de alunos de escolas públicas e privadas podem servir a esse processo como um elemento que vai trazer para as novas gerações uma noção positiva de civismo. Portanto, a visitação pode contribuir para evitar que essas gerações sejam influenciadas pelos 
aspectos históricos negativos que vivem na lembrança dos brasileiros, desde a época do Estado Novo, reforçados pela ditadura militar.

A natureza pedagógica das visitações ao Palácio do Planalto fica comprovada, quando se compara o roteiro da visita, os conteúdos repassados e a própria representação do Palácio com o que se prevê teoricamente para as viagensaula (citadas desde a década de 20), isto é, a aprendizagem.

A importância desses resultados para a formação cidadã dos alunos é tão grande, que a experiência pode passar a ser desenvolvida no âmbito do Turismo Cívico, através de ações associadas ao turismo pedagógico ou educativo, como as viagens-aulas.

Essas ações seriam estendidas a escolas das demais unidades da federação, por meio do Programa de Visitação Pública da COREP, e os respectivos deslocamentos até a capital federal representariam o turismo propriamente dito, porque haveria a injeção de recursos financeiros na economia da cidade.

Ficou claro, nos documentos pesquisados, que há um interesse grande nessas visitações por parte do governo federal, como bem demonstra o Programa de Visitação coordenado pela COREP e suas várias opções de visita das escolas.

Trazer para Brasília escolas de outras unidades da federação seria, portanto, ampliar a ação do governo federal nesse sentido, o que iria depender somente de articulações desse com os outros dois níveis de governo. As visitações escolares podem ocorrer também, nessas unidades, a título de premiação, como é em Brasília.

O Turismo Cívico é uma das possibilidades de se ampliar a conscientização sobre os valores da democracia, o sentimento patriótico e a identificação com as raízes culturais. É quando o estudante tem a possibilidade de confirmar na prática o que estudou em teoria, e o cidadão reafirmar os conceitos conexos.

Recomenda-se a realização de outros estudos onde se investiguem estudantes e professores que fizeram a visitação para consolidar informações e conhecimentos acerca dos temas de importância para o exercício da cidadania. 


\section{BIBLIOGRAFIA}

BRASIL. Ministério do Turismo. Turismo cultural 2006. Disponível em:<http: //www.dominiopublico.gov.br/download/texto/tu000019.pdf> Acesso em 23 jun 2009 BRASIL. Ministério do Turismo. Turismo cultural. Orientações básicas. Brasília: MTur, 2006a.

BRASÍLIA. Fundação Oscar Niemeyer. Pesquisa e Documentação - Sede . Brasília, 2009. Disponível em: <http://www.niemeyer.org.br/sede.htm> Acesso em 20 jun. 2009.

BRASÍLIA. Guia de Brasília. In: Brasília, Patrimônio Cultural da Humanidade. Brasília. Disponível em: <http://www.guiadebrasilia.com.br/ historico/ menupat.htm > Acesso em: 15 jun. 2009.

BRASÍLIA. Presidência da República. Um novo modelo de desenvolvimento. Brasília, 2009 Disponível em:<http://www.presidencia.gov.br/info_historicas.htm> Acessado em: 5 jul. 2009.

BRASILIATUR. Segmentos do Turismo. 2006. Disponível em: < www.turismo.gov. br> Acesso em: 30 agos 2009.

CÂMARA. Turismo. Disponível em: <http://www2.camara. gov.br/internet /banco imagem> Acesso em: 30 agos 2009.

CANCELLI, Elizabeth. O mundo da Violência: a polícia da era Vargas. 4. ed. Brasília: Universidade de Brasília, 1993.

CASTRO, Celso Antonio P. Sociologia aplicada ao turismo. São Paulo: Atlas, 2002. 
DELAMÔNICA, Ana Cristina. Projetos mato-grossenses concorrem ao Prêmio. 2002. Disponível em: < http://www.secom.mt.gov.br/imprime.php? cid=1604\&sid=13> Acesso em: 30 agos 2009 .

FREIRE, Paulo. Pedagogia da autonomia: saberes necessários à prática educativa. 34 ed. São Paulo: Paz e Terra, 1996.

GiL, Antonio Carlos. Métodos e técnicas de pesquisa social. 5. Ed. São Paulo: Atlas, 2007

HORTA, Maria de Lourdes Parreiras. Guia básico de educação patrimonial. Brasília: Museu Imperial / IPHAN, 1999.

LICKORISH, Leonard; JENKINS, Carson L. Introdução ao turismo. Rio de Janeiro: Campus, 2000.

LOTTICI KRAHL, Mara Flora. O turismo rural e a ressignificação da paisagem. Dissertação (Mestrado em Planejamento e Gestão Ambiental no Bioma Cerrado). Brasília, 2002. Universidade Católica de Brasília.

LUCK, Heloísa. Pedagogia interdisciplinar. Petrópolis: Vozes, 1994.

MOLETTA, Vania F. Turismo cultural. 3 ed. Porto Alegre: SEBRAE/RS, 2001

OMT. Organização Mundial de Turismo. Introdución al Turismo. Madrid: OMT, 1999a.

OMT. Organização Mundial de Turismo. Introdución al Turismo. Madrid: OMT, 1998.

PECOTCHE, Carlos Bernardes Gonzáles. Bases para sua conduta. 14. ed São Paulo: Logosófica, 1998.

PINHEIRO, Celso A Pinheiro. Sociologia aplicada ao Turismo. 2. ed. Rio de Janeiro: Atlas, 2008.

RAYKIL, Eladyr Boaventura; RAYKIL, Cristiano. Eficácia das viagens de estudo nas praticas de ensino. 2005. Disponível em: <http://www.etur.com.br/conteudo completo. asp?idconteudo=7678> Acesso em: 30 agos 2009.

RICHARDSON, R. J. e cols. Pesquisa social. Métodos e técnicas. 3. ed. São Paulo: Atlas, 1999. 
ROLLEMBERG, Rodrigo. Estímulo ao turismo do DF. Brasília, 2009. Disponível em:<http://www.google.com.br/search?hl=pt-\&q=rolemberg+o+turismo+de+brasilia \&meta.htm> Acesso em 12 jun. 2009

SANTOS FILHO, João. O turismo na era Vargas e o Departamento de Imprensa e Propaganda. Brasília. Cultur Revista de Turismo e Cultura, a 2, n. 2, 2008. Disponível em: <www.uesc.br/revistas/culturaeturismo> Acesso em 12 jun. 2009.

SHAFTESBURY, L.; LICKORISH, L. Orígenes del turismo. El Grand Tour y los viajeros ilustrados en Europa. Madrid, 2000.

STJ. Superior Tribunal de Justiça. STJ fará parte do roteiro do turismo cívico na capital da República. 2000. Disponível em: <www.direito2.com.br> Acesso em: 30 agos 2009

VERGARA, Sylvia C. Projetos e Relatórios de Pesquisa em Administração. 4 ed. São Paulo: Atlas, 2003. 


\section{ANEXOS}

ANEXO A - Fotografias

ANEXO B - Modelo do questionário

ANEXO C - Lista de exposições no Palácio do Planalto de 2006 à 2008 
ANEXO A

Todas as fotografias abaixo apresentadas são de autoria deste pesquisador.

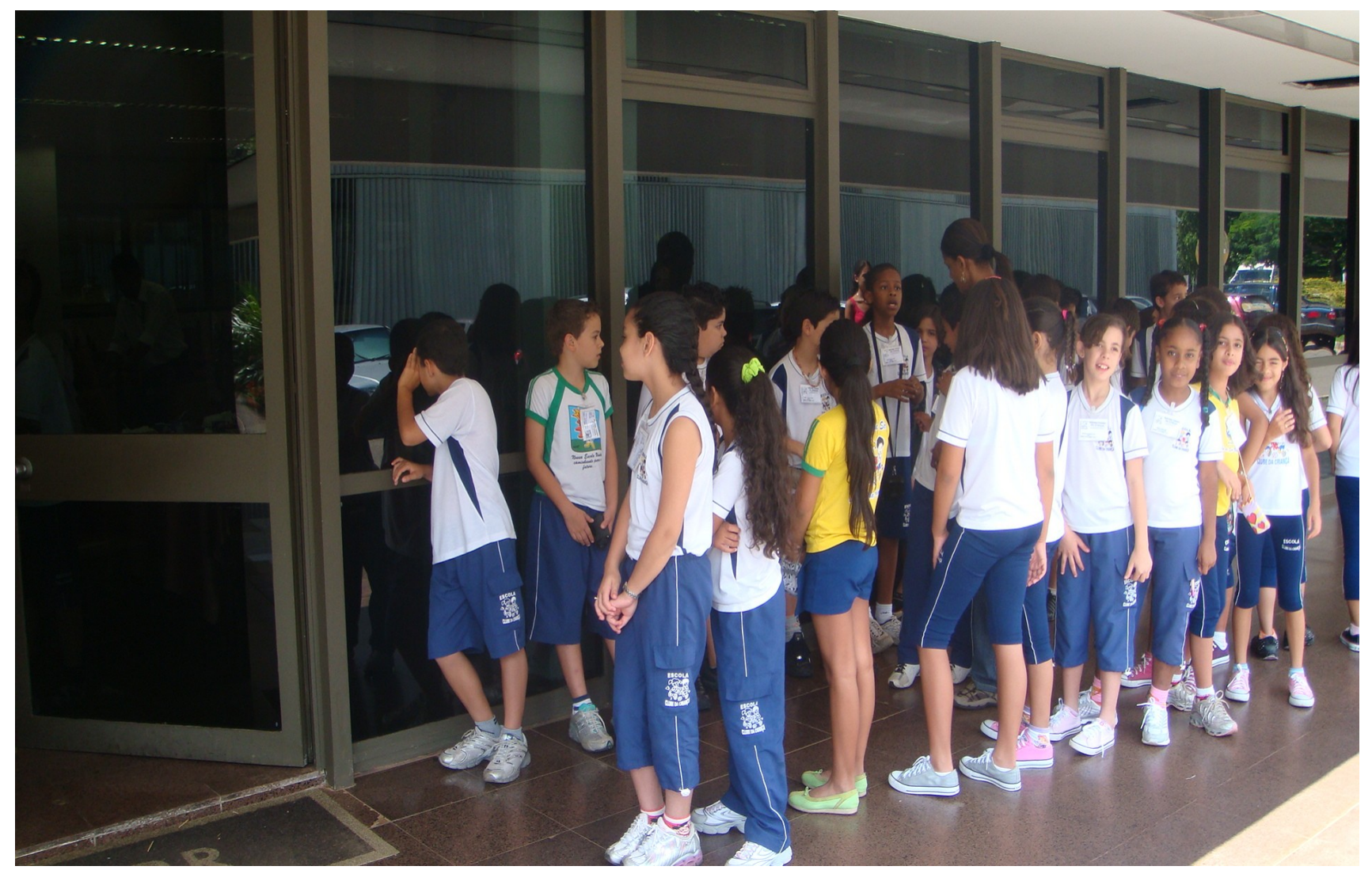

Foto 1 - Preparativo para o inicio da visitação. 


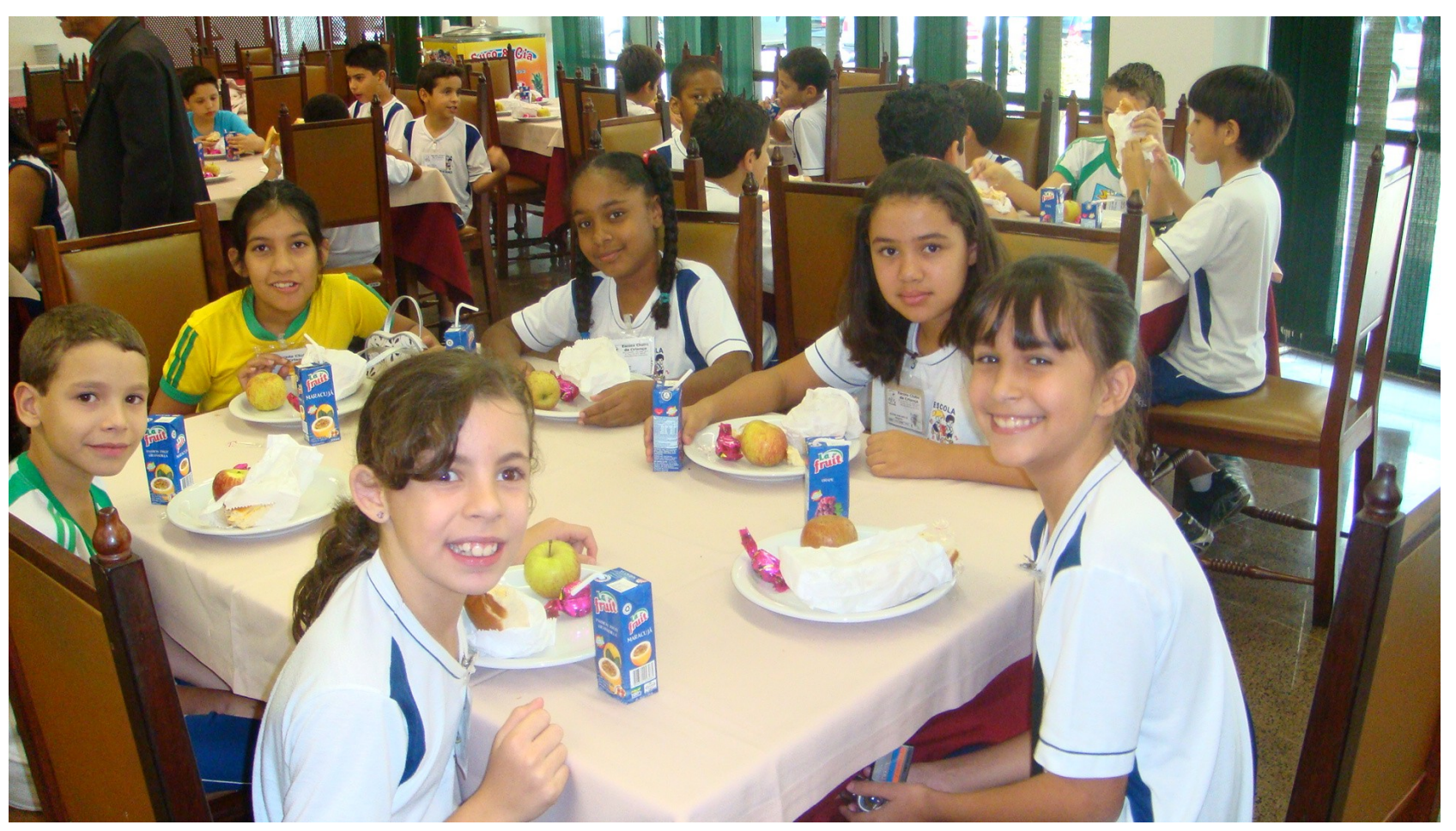

Foto 2 - Lanche dos alunos.

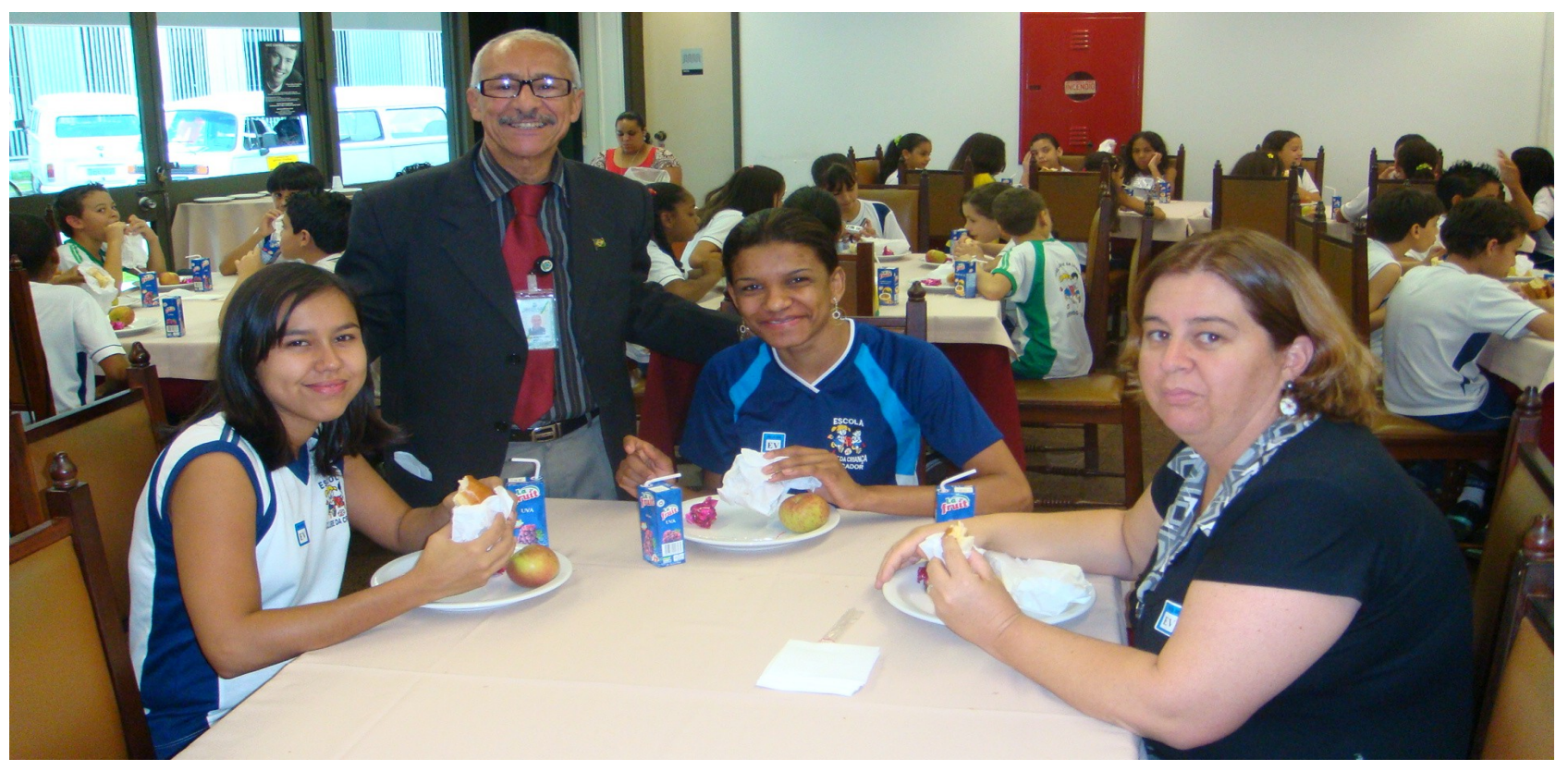

Foto 3 - Lanche com os professores e guia. 


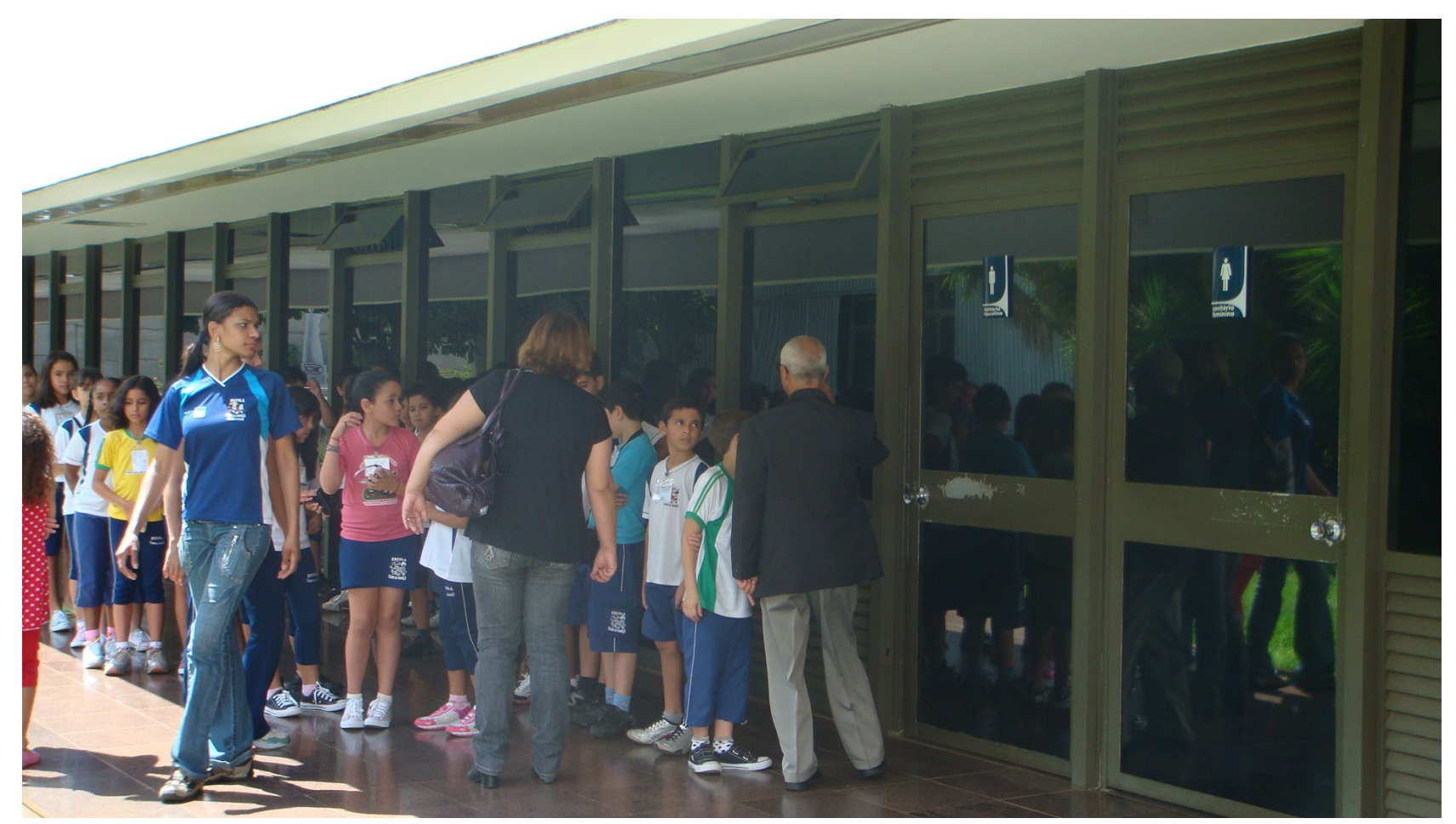

Foto 4 - Banheiros masculinos e femininos.

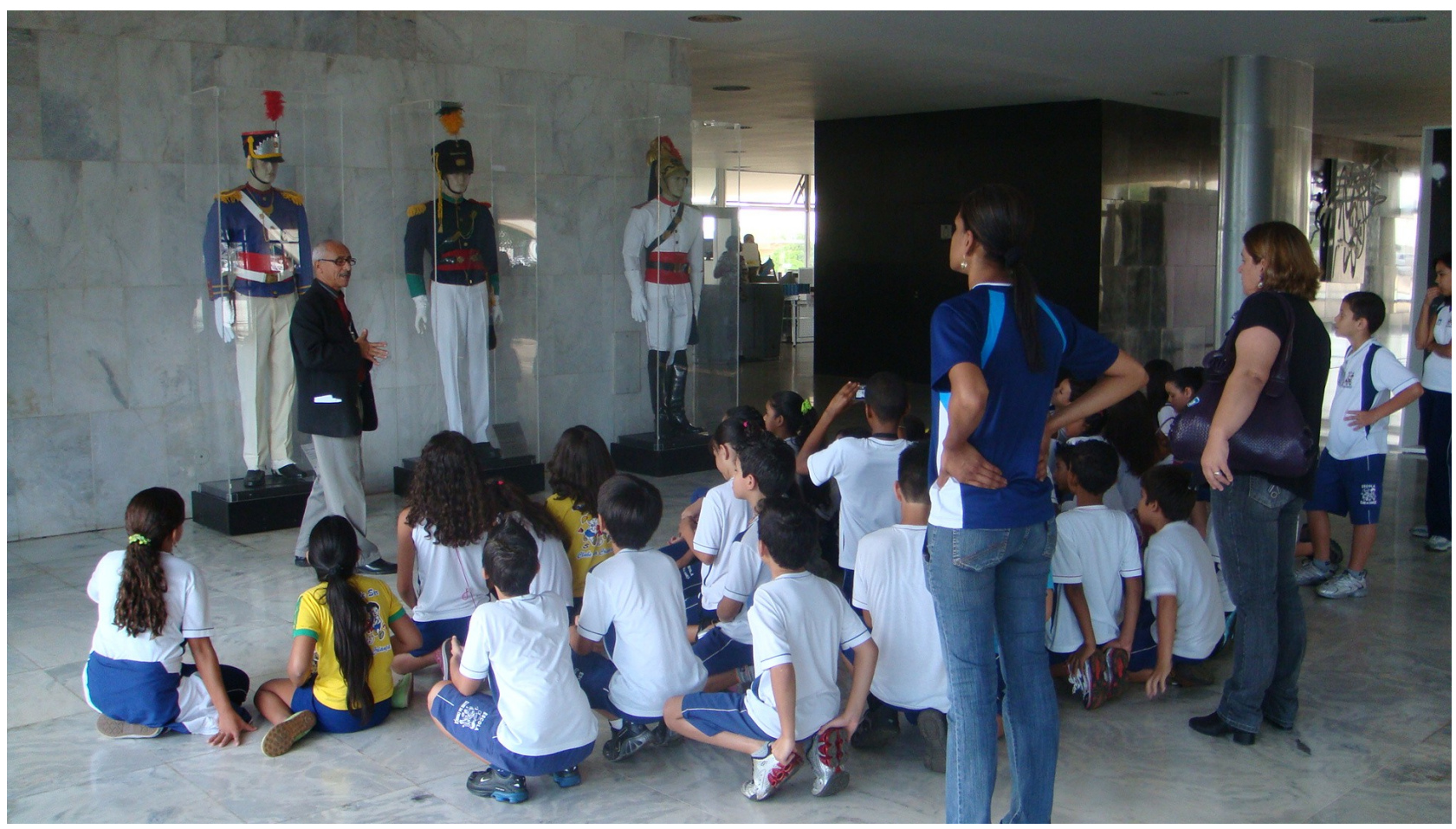

Foto 5 - Apresentação dos uniformes históricos. 


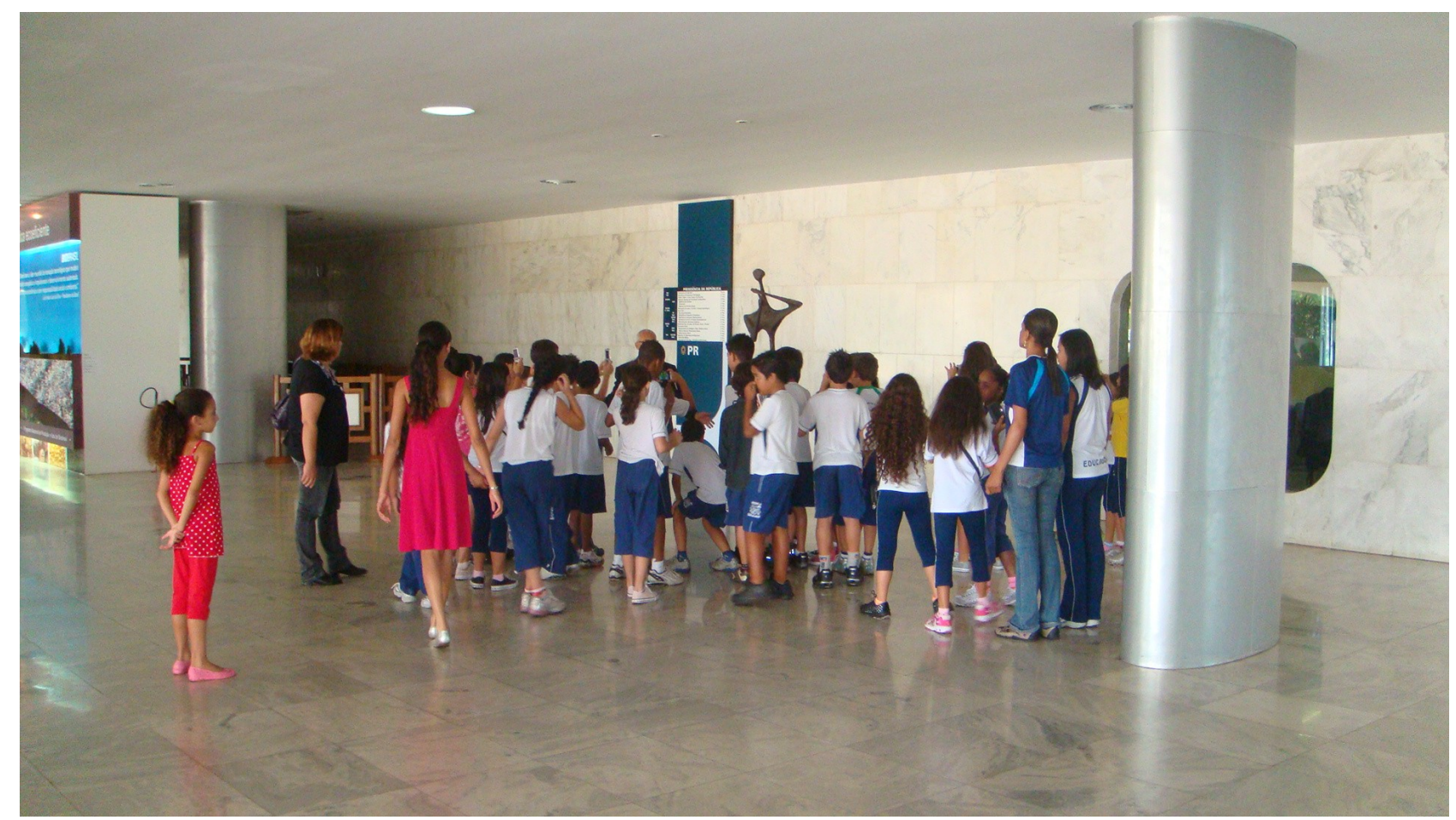

Foto 6 - Apresentação de escultura.

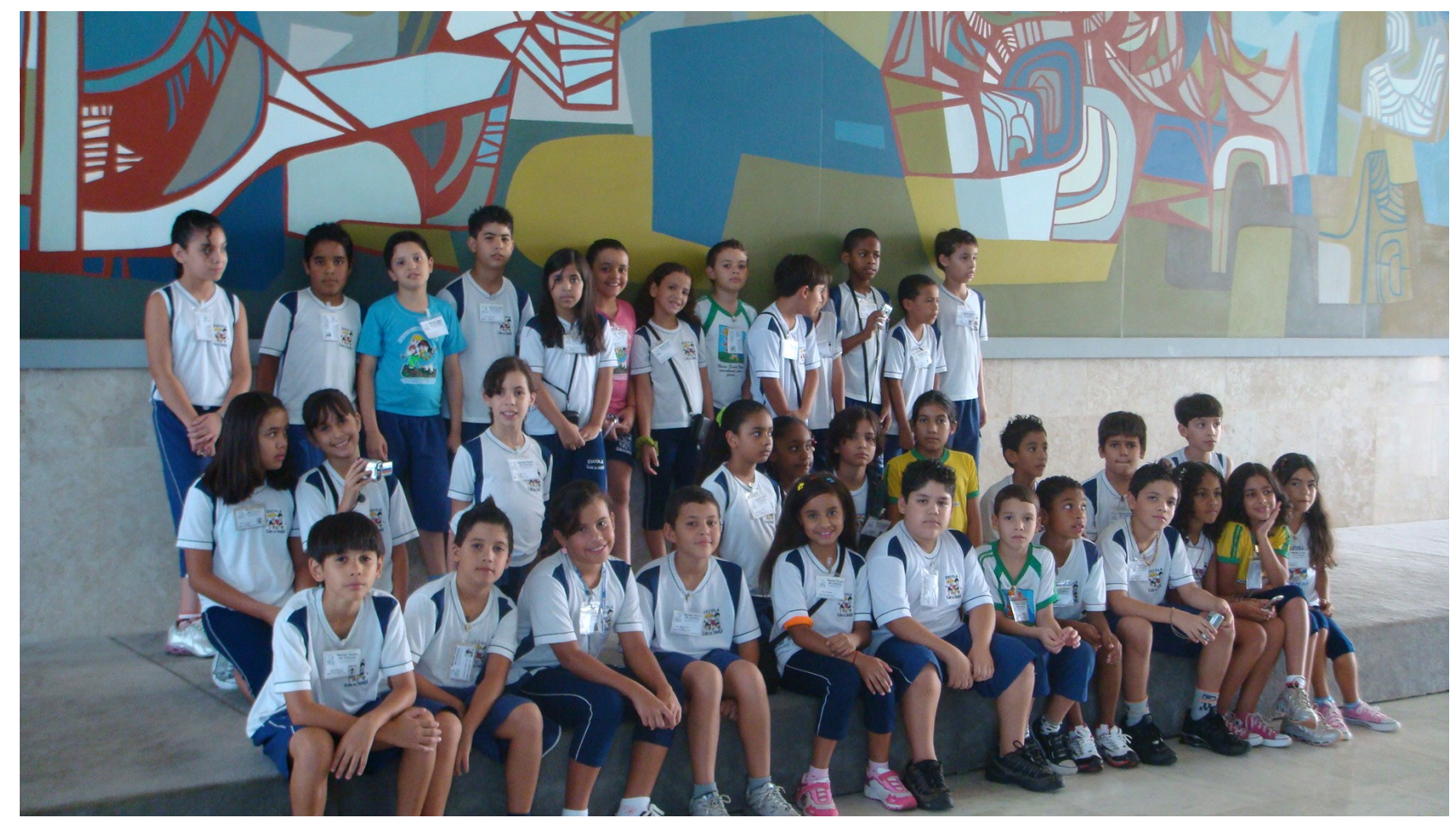

Foto 7 - Preparativo para foto oficial. 


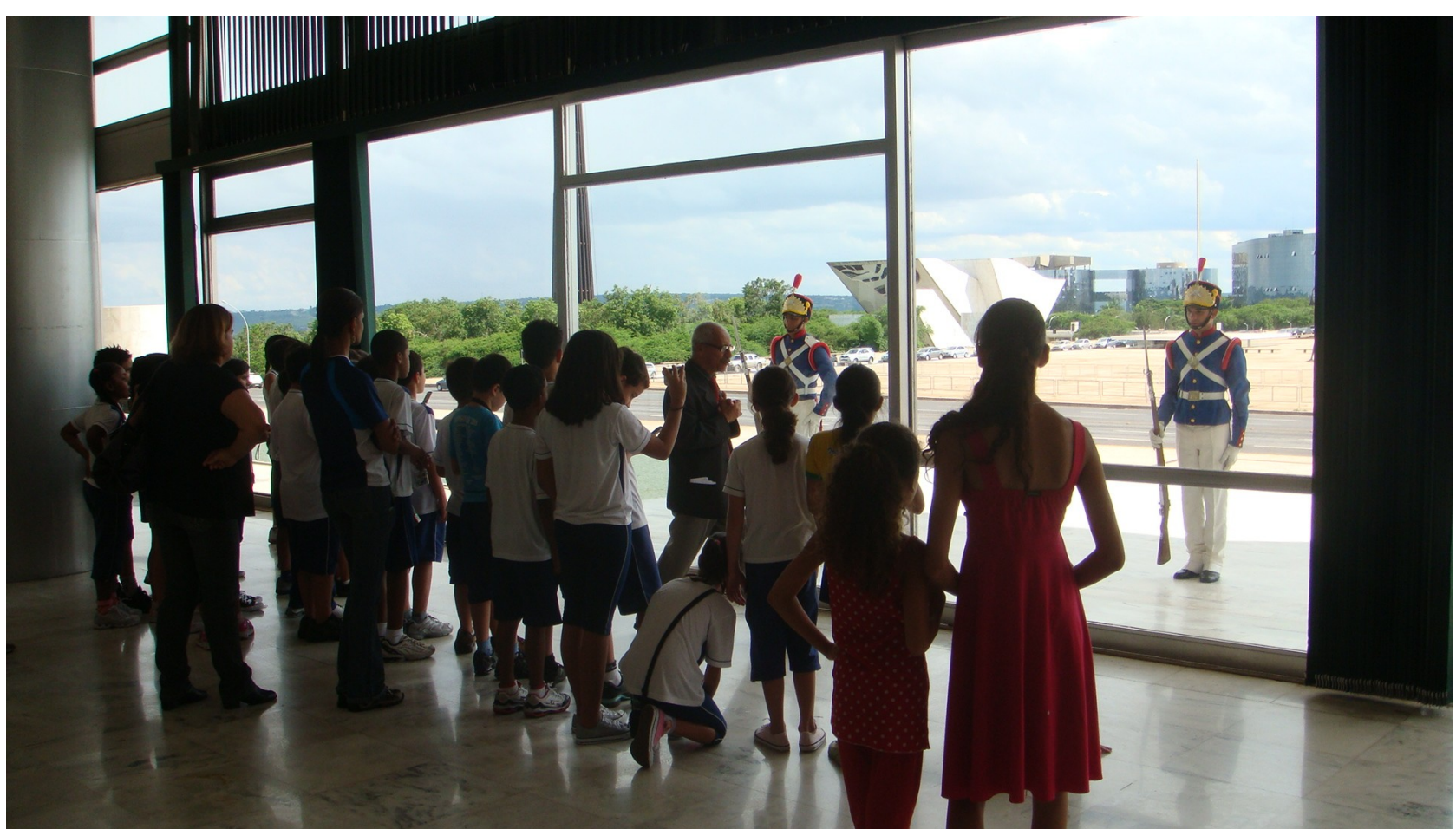

Foto 8 - Movimento de armas na rampa Presidencial.

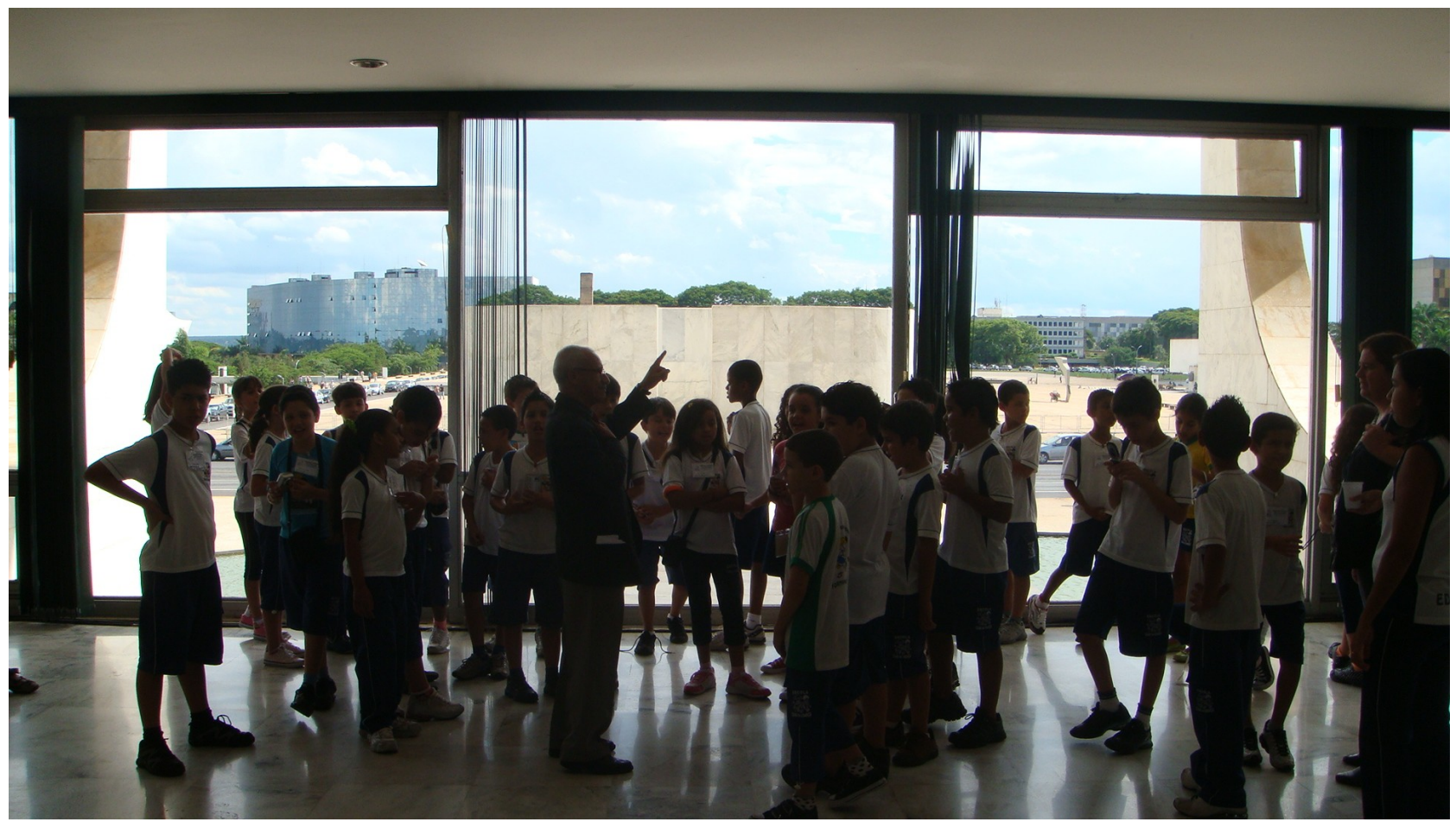

Foto 9 - Apresentação do parlatório. 


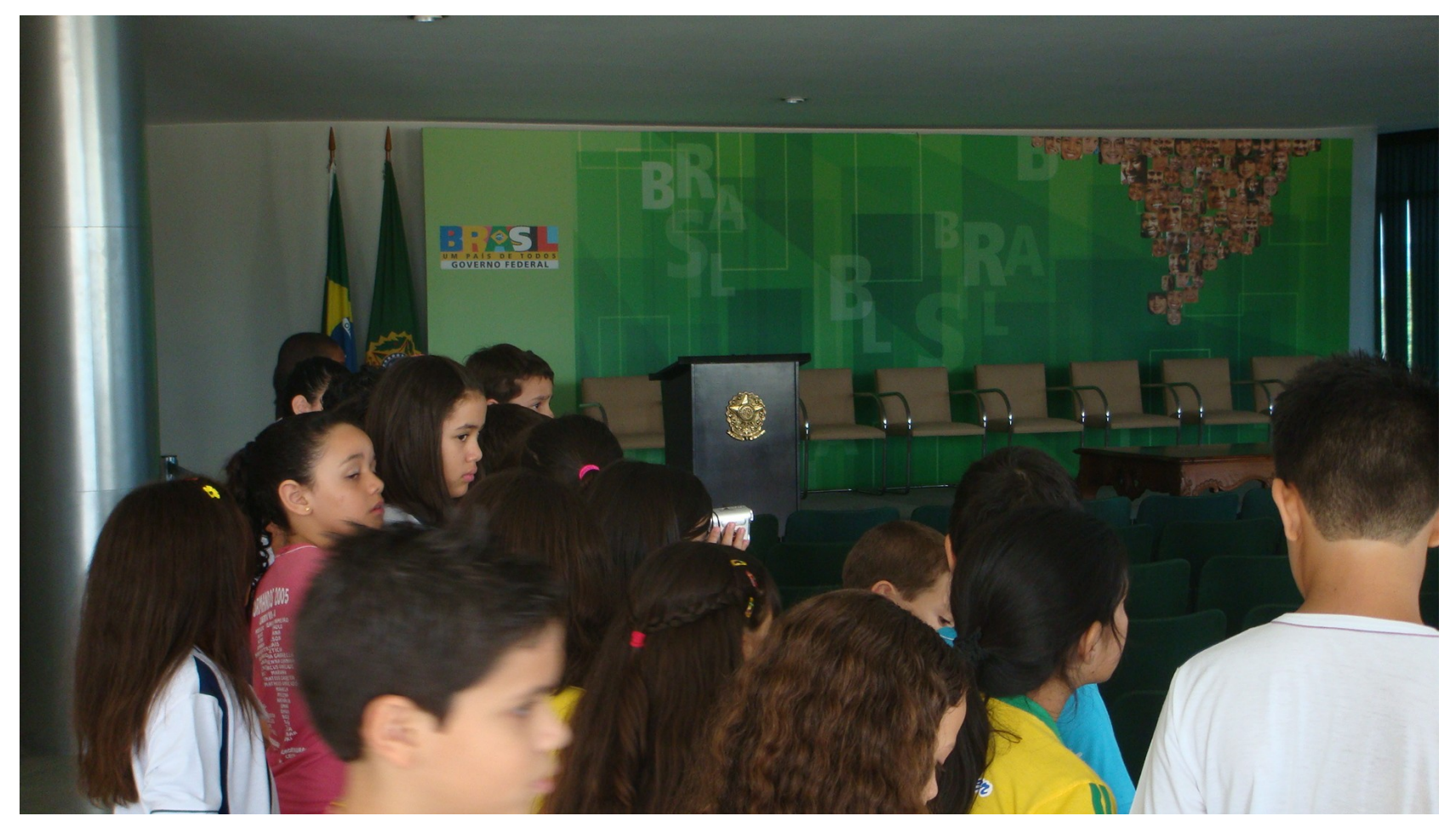

Foto 10 - Salão Leste.

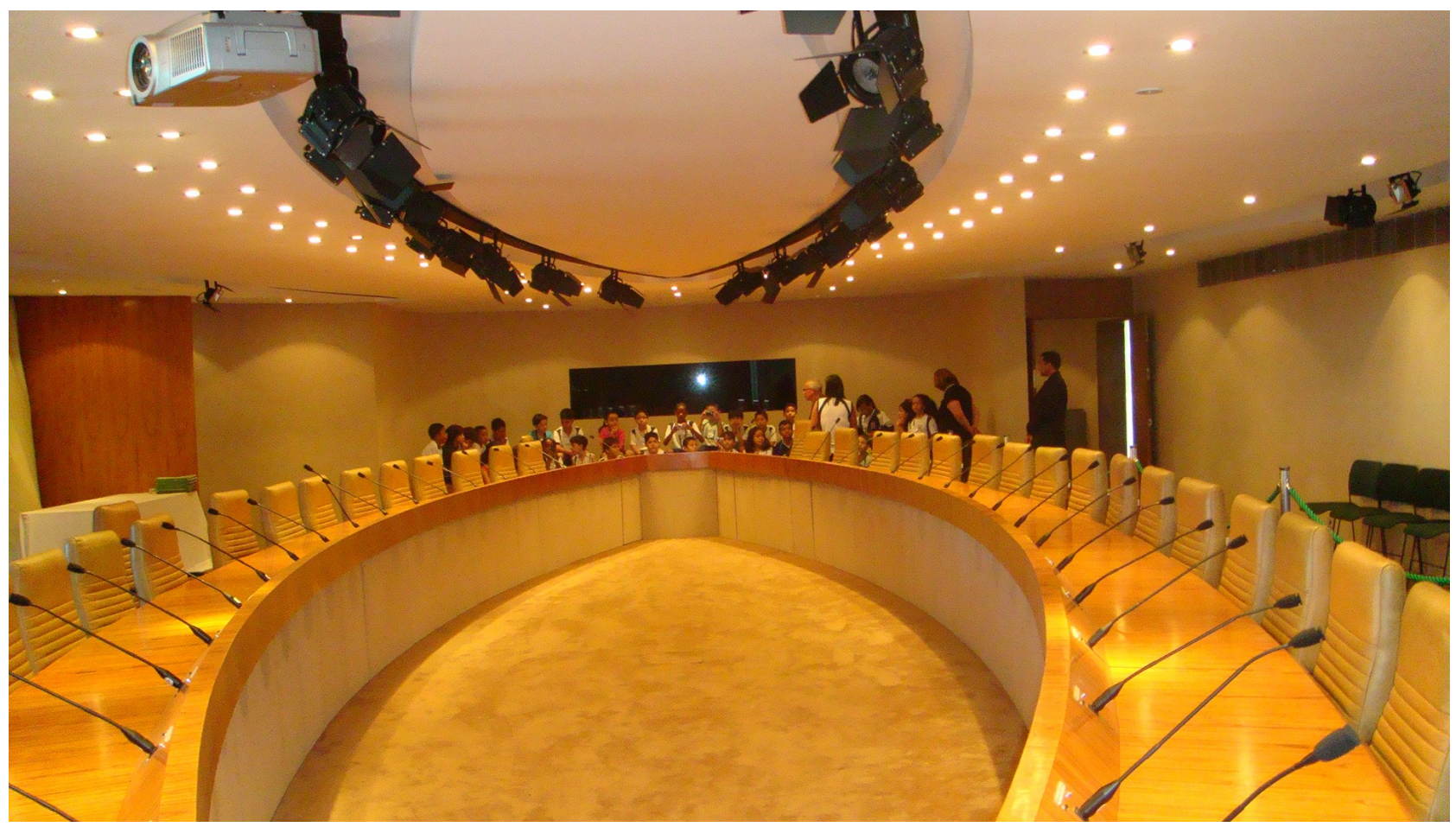

Foto 11 - Salão oval. 


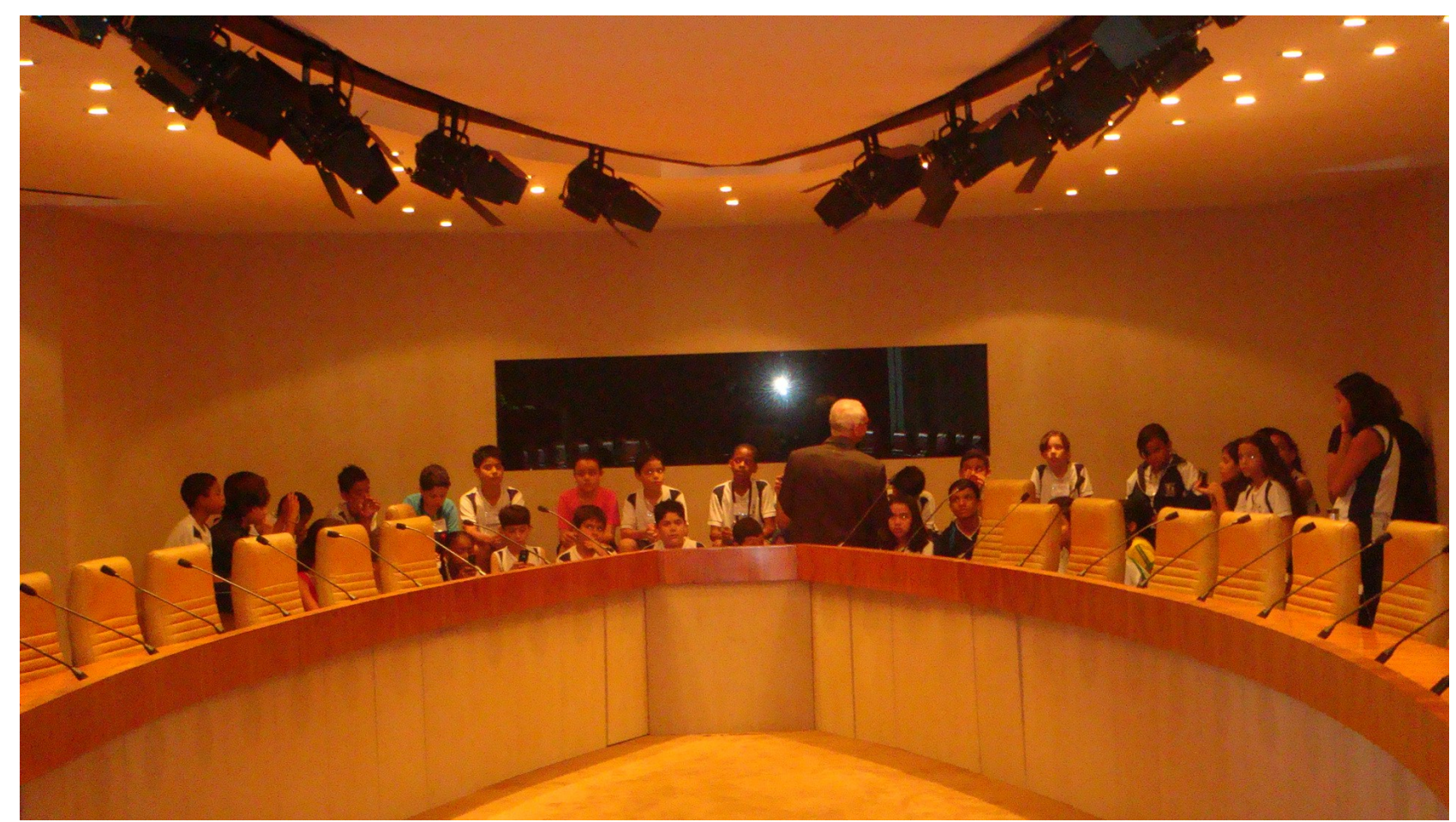

Foto 12 - Salão oval.

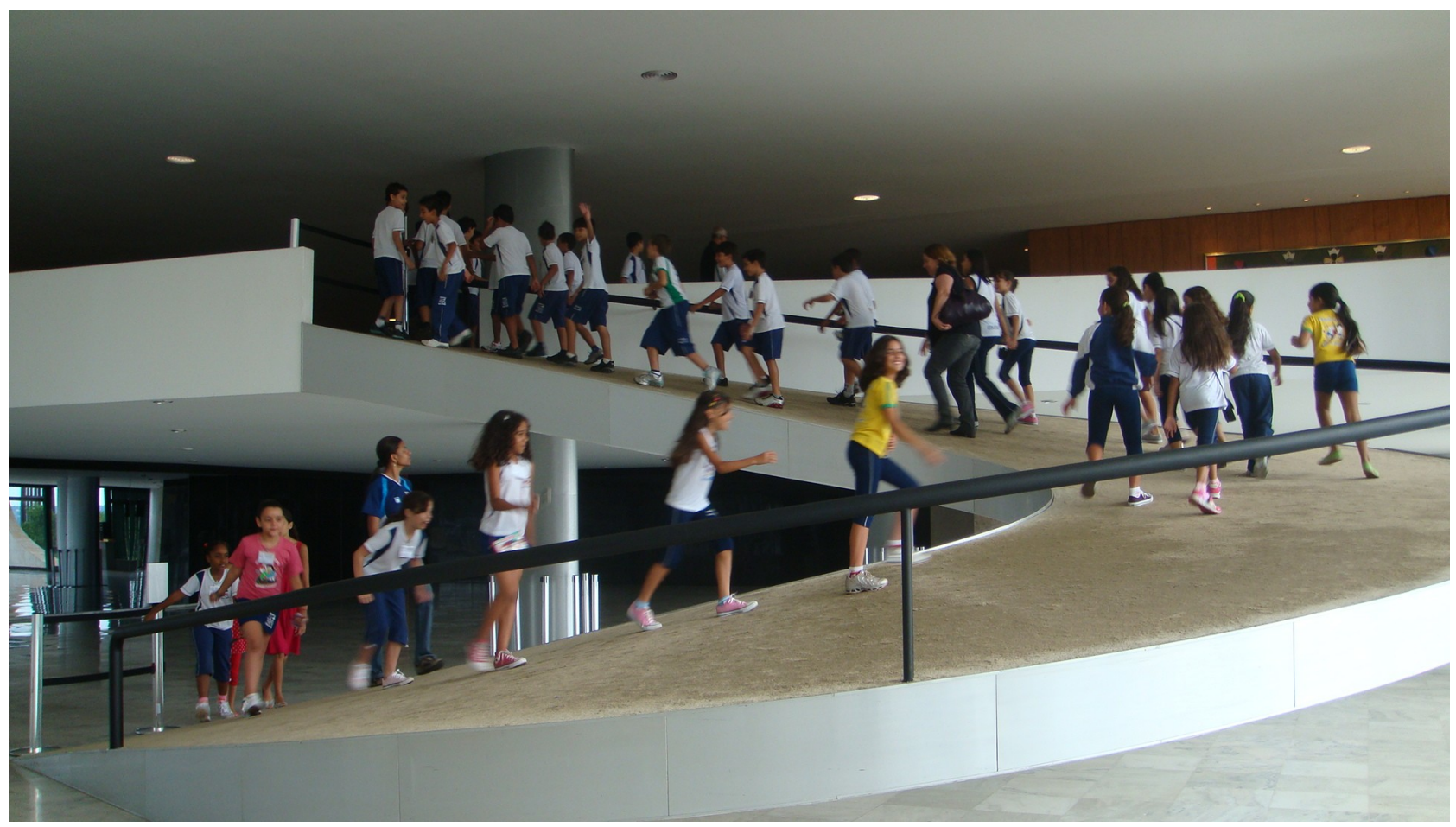

Foto 13 - Rampa interna. 


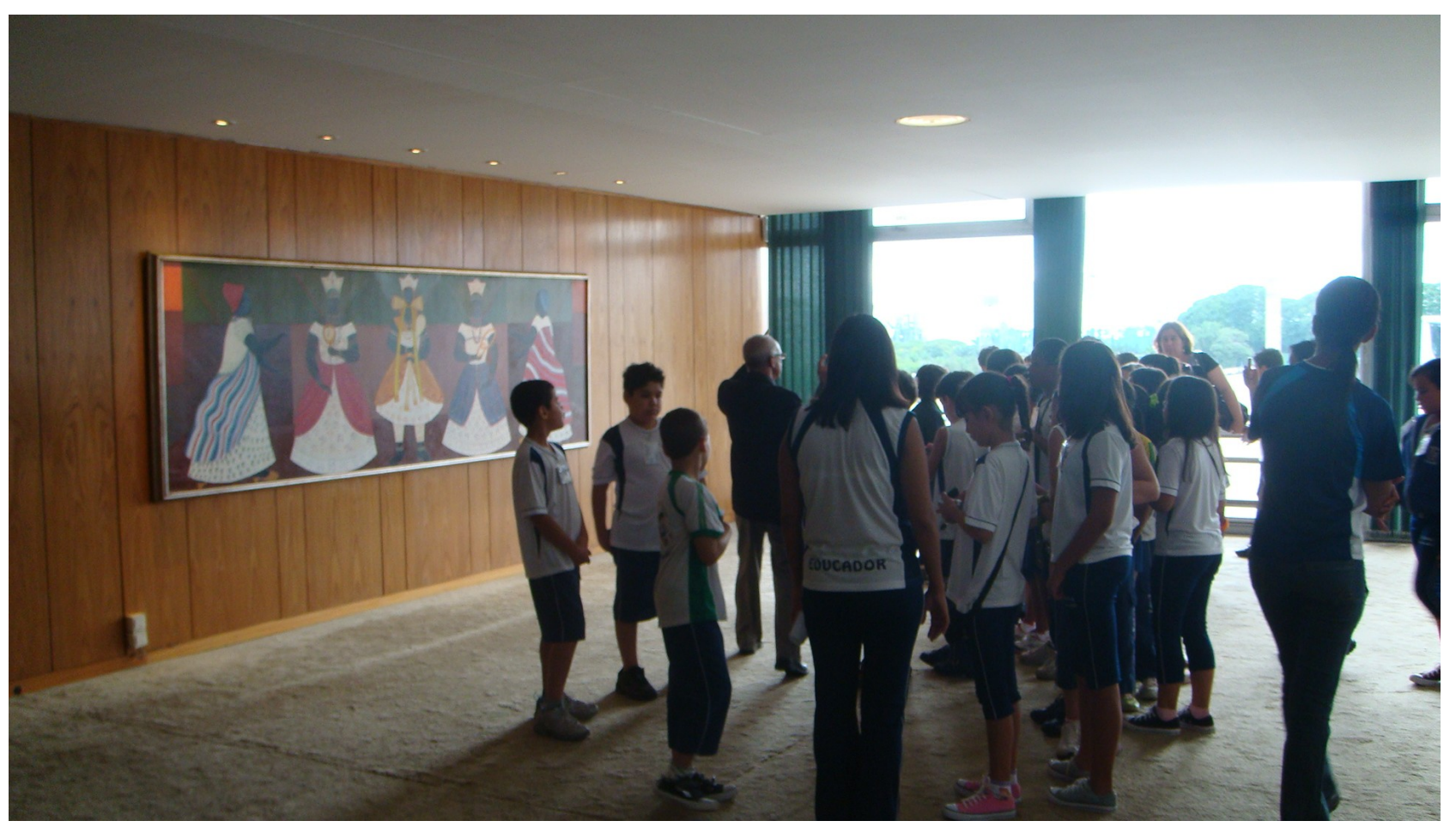

Foto 14 - Obra de arte. 

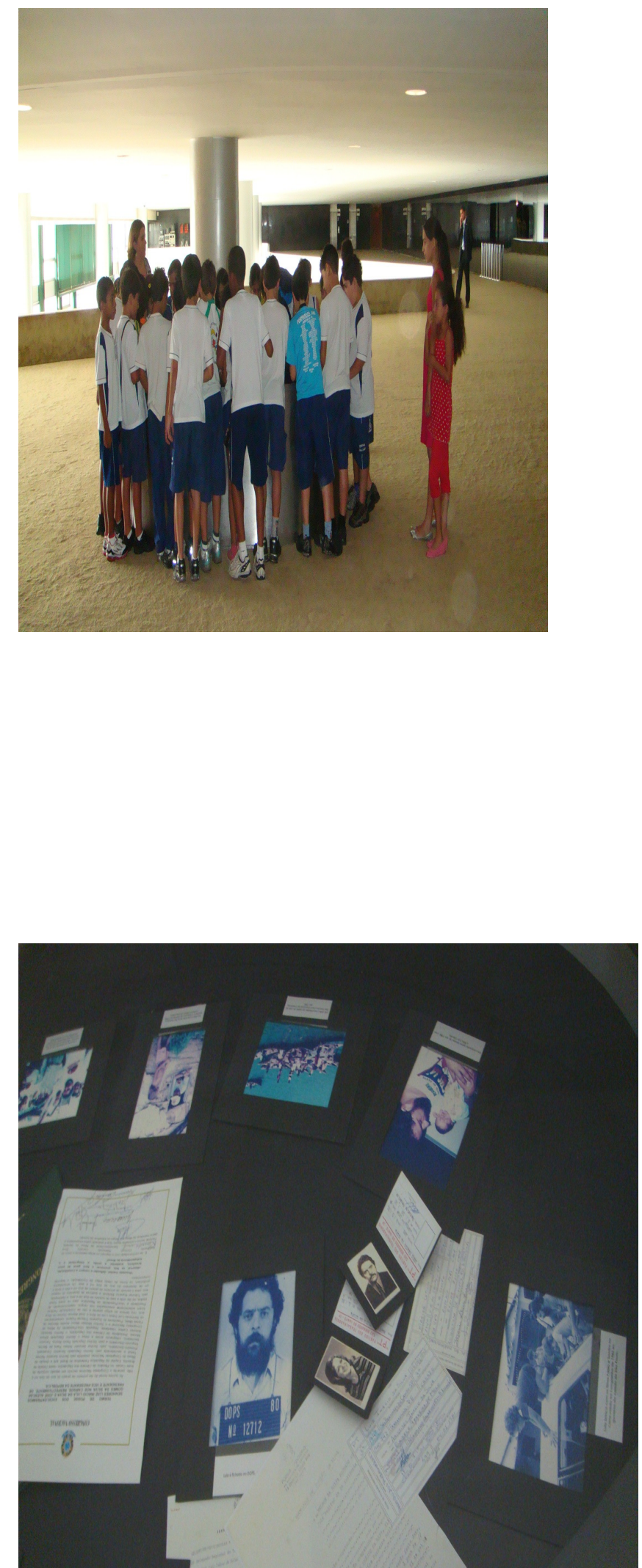

Foto 15 - Documentos pessoais do Presidente Lula. 


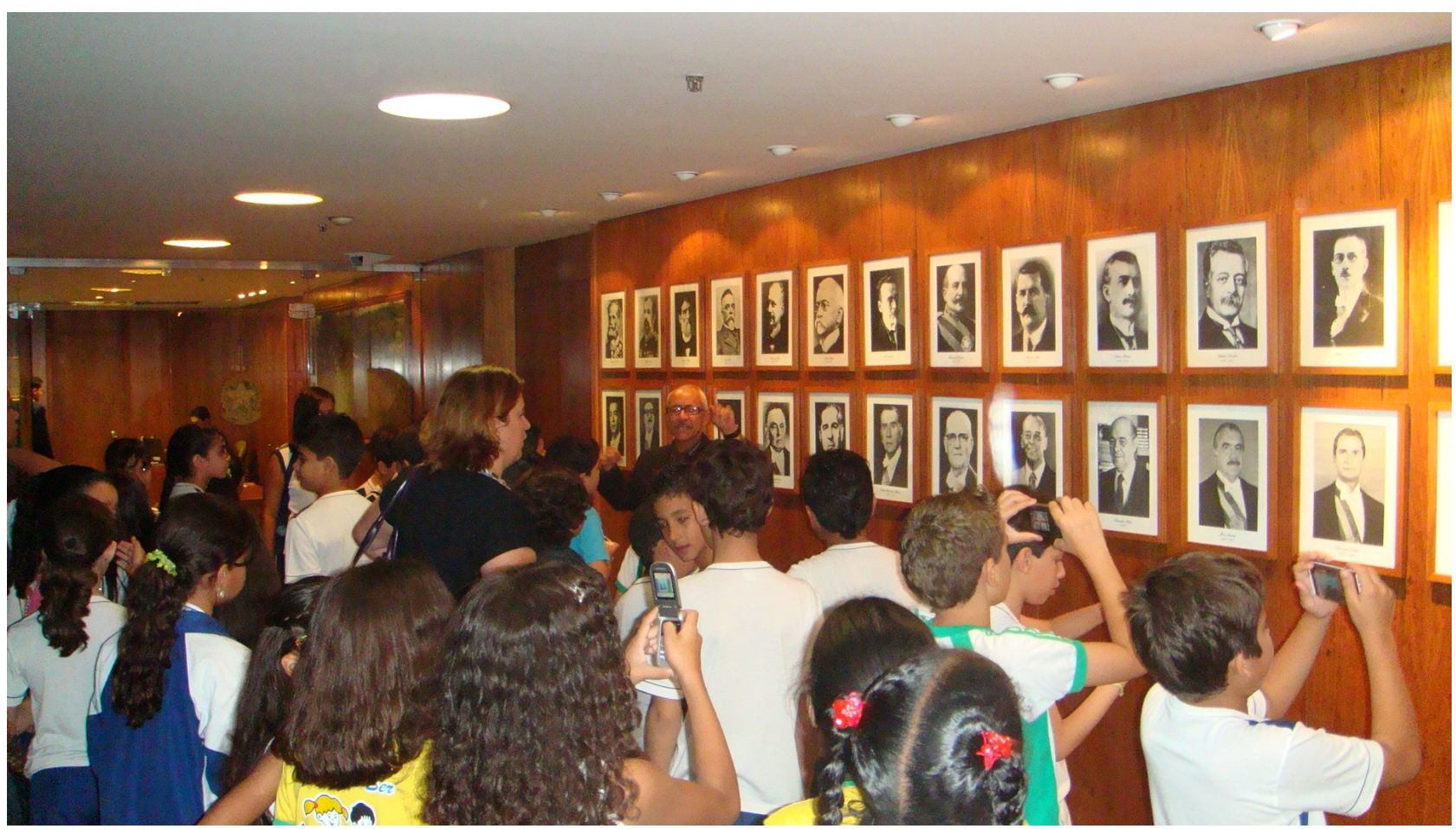

Foto 16 - Galeria de ex-presidentes.

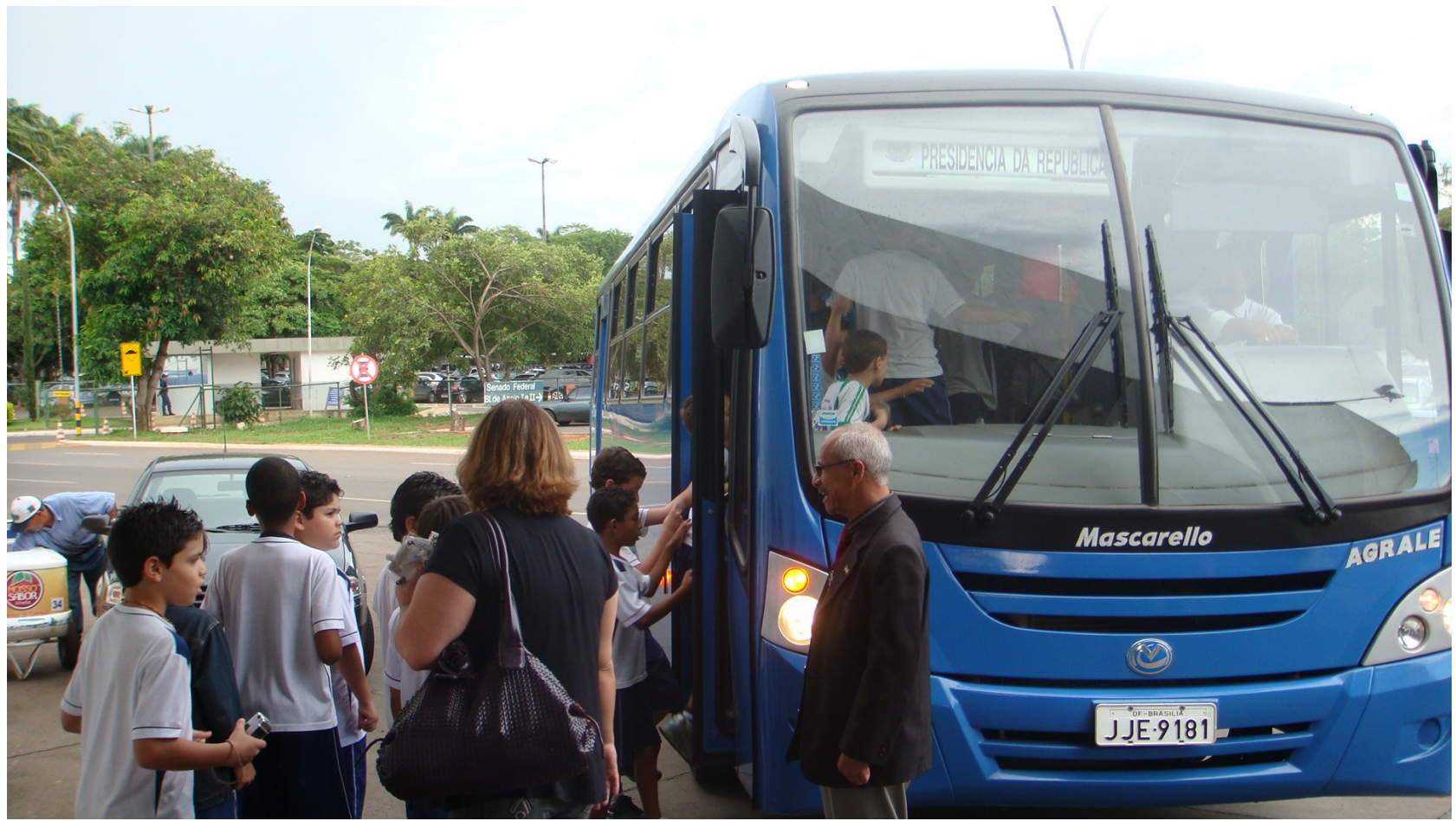

Foto 17 - Despedidas. 


\section{ANEXO B}

\section{AVALIAÇÃO DE VISITA AO \\ PALÁCIO DO PLANALTO}

Caro visitante,

Sua opinião sobre a visita realizada ao Palácio do Planalto, Sede do Poder Executivo brasileiro, é muito importante para que possamos melhorar constantemente o nosso programa.

Caso deseje, responda às questões abaixo.

E muito obrigado.

\section{Programa de Visitação Pública ao Palácio do Planalto} Agradecemos sua opinião sobre a visita.

1. Como você tomou conhecimento do Programa de Visitação ao Palácio do Planalto?

Palácio do Planalto ( ) Amigos ( ) Imprensa ( )

Praça dos Três Poderes ( ) Outros ( )

2. Você gostou da visita? $\operatorname{Sim}(\quad)$ Não ( )

Por quê?

2.1 Conteúdo das informações: Bom ( ) Ruim ( )

Por quê?

2.2 Cordialidade no atendimento: Bom ( ) Ruim ( )

Por quê?

2.3 Roteiro da visita: Bom ( ) Ruim ( )

Por quê?

2.4 Instalações do Palácio do Planalto (limpeza, conservação etc.): Boas ( ) Ruins ( ) Por quê?

3. Grau de instrução: Fundamental ( ) Médio ( ) Superior ( )

4. Procedência: DF ( ) Outros estados ( ) Outros países ( )

5. Comentários:

Caso deseje, identifique-se.

Nome:

Endereço:

E-mail:

PRESIDÊNCIA DA REPÚBLICA

CASA CIVIL

Secretaria Executiva

Coordenação de Relações Públicas 


\section{ANEXO C}

Exposições no Palácio do Planalto de 2006 à 2008

\section{6}

\begin{tabular}{|c|c|c|c|c|c|}
\hline $\mathbf{N}^{\circ}$ & $\begin{array}{c}\text { NOME DA } \\
\text { EXPOSIÇÃO }\end{array}$ & $\begin{array}{c}\text { INSTITUIÇÃO } \\
\text { ORGANIZADORA }\end{array}$ & PERÍODO & DESCRIÇÃO & PÚBLICO \\
\hline 1 & $\begin{array}{l}\text { Programa de } \\
\text { bibliotecas rurais } \\
\text { Arca das Letras }\end{array}$ & $\begin{array}{l}\text { Ministério da Reforma } \\
\text { Agrária }\end{array}$ & $\begin{array}{l}20 / 01 \quad a \\
10 / 02 / 2006\end{array}$ & $\begin{array}{l}\text { Mostra fotográfica e } \\
\text { apresentação de } \\
\text { vídeo }\end{array}$ & 3.500 \\
\hline 2 & $\begin{array}{l}\text { Fases do } \\
\text { desenvolvimento }\end{array}$ & $\begin{array}{l}\text { Banco Interamericano } \\
\text { de Desenvolvimento - } \\
\text { BID }\end{array}$ & $\begin{array}{l}16 / 02 \quad a \\
01 / 03 / 2006\end{array}$ & $\begin{array}{l}\text { Mostra fotográfica e } \\
\text { apresentação de } \\
\text { vídeo }\end{array}$ & 8.500 \\
\hline 3 & $\begin{array}{l}\text { Acervo do Prêmio } \\
\text { Nacional da } \\
\text { Gestão Pública }\end{array}$ & $\begin{array}{l}\text { Ministério do } \\
\text { Planejamento, } \\
\text { Orçamento e Gestão }\end{array}$ & $\begin{array}{l}13 / 02 \quad a \\
20 / 02 / 2006\end{array}$ & $\begin{array}{lr}\text { Mostra } & \text { de } \\
\text { documentos } & \text { e } \\
\text { apresentação } & \text { de } \\
\text { vídeo } & \end{array}$ & 11000 \\
\hline 4 & Proeja & $\begin{array}{l}\text { Ministério da } \\
\text { Educação }\end{array}$ & $\begin{array}{l}06 / 03 \quad a \\
16 / 03 / 2006\end{array}$ & $\begin{array}{l}\text { Mostra fotográfica } \\
\text { com o público-alvo } \\
\text { do programa }\end{array}$ & 4.500 \\
\hline 5 & $\begin{array}{l}\text { Exposição } \\
\text { Programa de } \\
\text { Sisternas }\end{array}$ & $\begin{array}{l}\text { Ministério de } \\
\text { Desenvolvimento } \\
\text { Social e Combate a } \\
\text { Fome }\end{array}$ & $\begin{array}{l}05 / 06 \quad a \\
10 / 06 / 2006\end{array}$ & Maquete e folhetos & \\
\hline 6 & $\begin{array}{l}\text { Programa espacial } \\
\text { brasileiro }\end{array}$ & $\begin{array}{l}\text { Agência Espacial } \\
\text { Brasileira (AEB) }\end{array}$ & $\begin{array}{l}20 / 03 \quad a \\
02 / 04 / 2006\end{array}$ & $\begin{array}{l}\text { Mostra de painéis e } \\
\text { maquetes }\end{array}$ & 1800 \\
\hline 7 & $\begin{array}{l}\text { A Epopéia de } \\
\text { Brasília }\end{array}$ & Mercedes Urquiza & $\begin{array}{l}10 / 04 / a \\
16 / 04 / 2006\end{array}$ & Mostra fotográfica & 2500 \\
\hline 8 & $\begin{array}{l}\text { A Arte da } \\
\text { Transformação - } \\
\text { Máscaras e Rituais }\end{array}$ & $\begin{array}{l}\text { Ministério da Cultura } \\
\text { Museu do Índio }\end{array}$ & $\begin{array}{l}18 / 04 \quad a \\
30 / 04 / 2006\end{array}$ & Painéis e multimídia & 12000 \\
\hline 9 & $\begin{array}{l}\text { O Brasil e Monte } \\
\text { Castelo - Por quê? } \\
\text { Como? Para quê? }\end{array}$ & $\begin{array}{l}\text { Ministério do Exército } \\
\text { Fundação Álvares } \\
\text { Penteado }\end{array}$ & $\begin{array}{l}7 / 05 \quad a \\
16 / 06 / 2006\end{array}$ & $\begin{array}{l}\text { Painéis, objetos, } \\
\text { fotografias e filmes }\end{array}$ & 15850 \\
\hline 10 & $\begin{array}{l}\text { VIII Semana Nac.I } \\
\text { Antidrogas }\end{array}$ & $\begin{array}{l}\text { Secretaria Nacional } \\
\text { Antidrogas - SENAD }\end{array}$ & $\begin{array}{l}9 / 06 \quad a \\
26 / 05 / 2006\end{array}$ & Painéis & 3500 \\
\hline 11 & Parixara & $\begin{array}{l}\text { DIRTI } \\
\text { COREP }\end{array}$ & $\begin{array}{l}23 / 10 \quad a \\
05 / 11 / 2006\end{array}$ & Pinturas & 10000 \\
\hline 12 & $\begin{array}{l}\text { Programa } \\
\text { Biodiesel }\end{array}$ & & $\begin{array}{l}\text { A partir de } \\
22 / 11 / 2006\end{array}$ & Painel & \\
\hline
\end{tabular}




\begin{tabular}{|c|c|c|c|c|c|}
\hline 13 & $\begin{array}{l}\text { A magia da vida, a } \\
\text { garra de um povo. }\end{array}$ & UNICEF & $\begin{array}{l}29 / 11 \quad a \\
04 / 12 / 2006\end{array}$ & Painéis e objetos & 3500 \\
\hline 14 & Prêmio Memória & $\begin{array}{l}\text { Fundação Banco do } \\
\text { Brasil }\end{array}$ & $13 / 12 / 2006$ & Painéis & 250 \\
\hline 15 & $\begin{array}{l}40 \text { anos da } \\
\text { Embratur }\end{array}$ & $\begin{array}{l}\text { Ministério do Turismo } \\
\text { e Embratur }\end{array}$ & $\begin{array}{l}21 / 12 \quad a \\
28 / 12 / 2006\end{array}$ & $\begin{array}{l}\text { Painéis fotográficos } \\
\text { e multimídia }\end{array}$ & 4200 \\
\hline
\end{tabular}

\section{7}

\begin{tabular}{|c|c|c|c|c|c|}
\hline $\mathbf{N}^{\circ}$ & $\begin{array}{l}\text { NOME DA } \\
\text { EXPOSIÇÃO }\end{array}$ & $\begin{array}{l}\text { INSTITUIÇÃO } \\
\text { ORGANIZADORA }\end{array}$ & PERÍODO & DESCRIÇÃO & PÚBLICO \\
\hline 01 & $\begin{array}{l}\text { Jogo de } \\
\text { Damas }\end{array}$ & $\begin{array}{l}\text { Museu República, } \\
\text { Secretária Especial } \\
\text { de Políticas para } \\
\text { Mulheres e apoio da } \\
\text { Caixa Ecônomica }\end{array}$ & $\begin{array}{l}09 / 03 \quad \text { à } \\
02 / 04\end{array}$ & $\begin{array}{l}\text { Pinturas, fotografias, } \\
\text { vestidos e presentes. }\end{array}$ & 1.000 \\
\hline 02 & $\begin{array}{l}5^{\text {a }} \text { Bienal de } \\
\text { Arquitetura de } \\
\text { Brasília } \\
\text { Monumenta }\end{array}$ & $\begin{array}{l}\text { IPHAN } \\
\end{array}$ & 11 à 29/04 & $\begin{array}{l}\text { Resultados do Programa } \\
\text { do ministério da Cultura - } \\
\text { IPHAN }\end{array}$ & 2.000 \\
\hline 03 & $\begin{array}{l}200 \text { Anos do } \\
\text { Judiciário }\end{array}$ & $\begin{array}{l}\text { Fundação Armando } \\
\text { Álvares Penteado }\end{array}$ & $\begin{array}{l}24 / 05 \quad \text { à } \\
12 / 06\end{array}$ & $\begin{array}{l}\text { Mostra das Sete } \\
\text { Constituições Brasileiras }\end{array}$ & 10.000 \\
\hline 04 & $\begin{array}{l}\text { Trabalhos } \\
\text { premiados em } \\
\text { concursos } \\
\text { promovidos } \\
\text { pela SENAD }\end{array}$ & SENAD & $\begin{array}{l}18 / 06 \quad \text { à } \\
23 / 06\end{array}$ & Cartazes & 500 \\
\hline 05 & $\begin{array}{l}\text { Xilografia e } \\
\text { Literatura de } \\
\text { Cordel }\end{array}$ & $\begin{array}{l}\text { Parte do acervo } \\
\text { particular do } \\
\text { colecionador e } \\
\text { pesquisador Geová } \\
\text { Franklin }\end{array}$ & $\begin{array}{l}27 / 06 \quad \text { à } \\
15 / 08\end{array}$ & $\begin{array}{l}\text { Gravuras decorativas, } \\
\text { matrizes, panos, cordéis e } \\
\text { álbuns }\end{array}$ & 1.500 \\
\hline 06 & $\begin{array}{l}\text { De Volta para } \\
\text { Casa }\end{array}$ & $\begin{array}{l}\text { Coordenação da Área } \\
\text { Técnica de Saúde } \\
\text { Mental }\end{array}$ & 3 à 17/09 & Fotos & 2.000 \\
\hline 07 & $\begin{array}{l}\text { Exposição do } \\
5^{\circ} \text { Encontro } \\
\text { Nacional do } \\
\text { PROMIMP }\end{array}$ & $\begin{array}{l}\text { Ministério de Minas e } \\
\text { Energia }\end{array}$ & 07 à $18 / 11$ & Fotos & 2.500 \\
\hline
\end{tabular}




\begin{tabular}{|c|c|c|c|c|c|}
\hline $\mathbf{N}^{0}$ & $\begin{array}{l}\text { NOME DA } \\
\text { EXPOSIÇÃO }\end{array}$ & $\begin{array}{l}\text { INSTITUIÇÃO } \\
\text { ORGANIZADORA }\end{array}$ & PERÍODO & DESCRIÇÃO & PÚBLICO \\
\hline 01 & Parapan & $\begin{array}{l}\text { Ministério do Turismo e } \\
\text { Observatório de } \\
\text { Favelas do Rio de } \\
\text { Janeiro }\end{array}$ & $\begin{array}{ll}13 / 02 & \text { à } \\
21 / 03 & \end{array}$ & Fotos & 4.000 \\
\hline 02 & Heróis de 58 & $\mathrm{CBF}$ & $\begin{array}{l}26 / 06 \\
\text { à } 26 / 07\end{array}$ & $\begin{array}{l}\text { Mostra } \\
\text { fotográfica e } \\
\text { de Vídeo }\end{array}$ & 3.000 \\
\hline 03 & $\begin{array}{l}\text { “68: } \\
\text { Calabouço ao Al- } \\
5 ”\end{array}$ & $\begin{array}{l}\text { Biblioteca da Imprensa } \\
\text { Nacional }\end{array}$ & $\begin{array}{ll}29 / 09 & \text { à } \\
10 / 10 & \end{array}$ & $\begin{array}{l}\text { Páginas de } \\
\text { Jornais }\end{array}$ & 350 \\
\hline 04 & $\begin{array}{l}\text { Transposição de } \\
\text { Uma Partilha }\end{array}$ & Fábio Brito & 06 á 17/10 & Tela & 500 \\
\hline
\end{tabular}

Algumas exposições realizadas, nos corredores dos anexos do palácio, 09 (nove) exposições, conforme tabela descritiva abaixo:

\section{EXPOSIÇÕES NOS ANEXOS}

\begin{tabular}{|l|l|l|l|l|}
\hline$N^{\circ}$ & \multicolumn{1}{|c|}{$\begin{array}{c}\text { NOME DA } \\
\text { EXPOSIÇÃO }\end{array}$} & \multicolumn{1}{|c|}{$\begin{array}{c}\text { INSTITUIÇÃO } \\
\text { ORGANIZADORA }\end{array}$} & DESCRIÇÃO & PÚBLICO \\
\hline 01 & $\begin{array}{l}\text { Painel } \\
\text { COREP } \\
\text { Dia das Mulheres }\end{array}$ & $\begin{array}{l}\text { Mostra } \\
\text { fotográfica }\end{array}$ & 2530 \\
\hline 02 & $\begin{array}{l}\text { Uma década de } \\
\text { combate dos } \\
\text { trabalho escravo }\end{array}$ & $\begin{array}{l}\text { Sindicato } \\
\text { Auditores Fiscais do } \\
\text { Trabalho-SINAT }\end{array}$ & Painéis e vídeo & 1500 \\
\hline 03 & $\begin{array}{l}\text { Programa de } \\
\text { Sisternas }\end{array}$ & $\begin{array}{l}\text { Ministério } \\
\text { Desenvolvimento } \\
\text { Social e Combate a }\end{array}$ & $\begin{array}{l}\text { Maquete } \\
\text { folhetos }\end{array}$ & 2500 \\
\hline
\end{tabular}




\begin{tabular}{|c|c|c|c|c|}
\hline & & Fome & & \\
\hline 04 & $\begin{array}{l}\text { Artesanato } \\
\text { solidário }\end{array}$ & $\begin{array}{l}\text { Instituto de } \text { Economia } \\
\text { Solidária } \\
\text { (IESI) }\end{array}$ & $\begin{array}{l}\text { Objetos } \\
\text { artesanais }\end{array}$ & 6200 \\
\hline 05 & Benditas fomes & $\begin{array}{l}\text { DIGEP - Programa de } \\
\text { Qualidade de Vida }\end{array}$ & Fotografias & 2.500 \\
\hline 06 & $\begin{array}{ll}\text { III Mostra } & \text { de } \\
\text { Talentos } & \text { da } \\
\text { Presidência } & \text { da } \\
\text { República } & \end{array}$ & COREP & $\begin{array}{l}\text { Artesanato } \\
\text { diversificado, } \\
\text { fotografia } \\
\text { pintura }\end{array}$ & 7500 \\
\hline 07 & $\begin{array}{l}\text { Artesanato em } \\
\text { cerâmica }\end{array}$ & $\begin{array}{l}\text { Cooperativa de } \\
\text { Artesãos de Brasília }\end{array}$ & $\begin{array}{l}\text { Peças de } \\
\text { cerâmica }\end{array}$ & 5000 \\
\hline 08 & $\begin{array}{ll}\text { Mostra } & \text { de } \\
\text { Artesanato } & \text { de } \\
\text { Brasília } & \\
\end{array}$ & $\begin{array}{l}\text { Cooperativas de } \\
\text { Artesãos }\end{array}$ & $\begin{array}{l}\text { Artesanato } \\
\text { diversificado }\end{array}$ & 4000 \\
\hline 09 & $\begin{array}{l}\text { Mostra Natalina } \\
\text { dos Servidores da } \\
\text { Presidência }\end{array}$ & COREP & $\begin{array}{l}\text { Objetos } \\
\text { artesanato }\end{array}$ & 7500 \\
\hline
\end{tabular}

